\title{
Anatomical Sites for Practicing Wet Cupping Therapy (Al-Hijamah): In Light of Modern Medicine and Prophetic Medicine
}

Hany Salah Mahmoud ${ }^{1}$, Moustafa Abou-El-Naga ${ }^{2,3}$, Nassar Ayoub Abdelatif Omar ${ }^{4,5}$, Hany Ali EI-Ghazzawy ${ }^{6}$, Yasser Mohamed Fathy ${ }^{7}$, Manal Mohamed Helmy Nabo ${ }^{8,9}$ and Salah Mohamed El Sayed ${ }^{10 *}$

${ }^{1}$ World Federation of Alternative and Complementary Medicine, Cairo Regional Headquarter, Cairo, Egypt

${ }^{2}$ Department of Anatomy and Embryology, Faculty of Medicine, Damaietta branch, Al-Azhar University, Egypt

${ }^{3}$ Department of Anatomy and Embryology, Faculty of Medicine, Rabigh branch, King Abdul-Aziz University, Saudi Arabia

${ }^{4}$ Department of Anatomy and Embryology, Faculty of Medicine, Sohag University, Egypt

${ }^{5}$ Department of Anatomy and Embryology, Faculty of Clinical Pharmacy, Taif University, Saudi Arabia

${ }^{6}$ Consultant group for Alternative and Complementary Medicine, Cairo, Egypt

${ }^{7}$ Department of Family Medicine, Atlas Health Centre, Ministry of Health, Egypt

${ }^{8}$ Department of Pediatrics, Sohag Teaching Hospital, Sohag, Egypt

${ }^{9}$ Department of Pediatrics, Maternity and Children Hospital, Al-Madinah Al-Munawwarah, Kingdom of Saudi Arabia

${ }^{10}$ Department of Medical Biochemistry, Sohag Faculty of Medicine, Sohag University, Egypt

\begin{abstract}
Wet cupping therapy (WCT) is increasingly practiced worldwide, especially in hospitals of China and Germany. Al-hijamah is WCT of prophetic medicine. Al-hijamah was recently reported to be more effective than Chinese WCT. Al-hijamah filters and clears blood and interstitial fluids from causative pathological substances (CPS) including disease-causing substances (DCS) and disease-related substances (DRS) according to the evidence-based Taibah theory. This occurs via a percutaneous pressure-dependent and size-dependent filtration of capillary blood of skin circulation. This explains why Al-hijamah treats diseases with different pathogeneses e.g. headache and rheumatoid arthritis. Hijamatology is a novel term describing the science of education, qualification, practice and research related to Al-hijamah. Al-hijamah was described by Prophet Mohammad (Muhammad) peace be upon him as one of the best remedies: "The best among what you use in therapy is Al-Hijamah and Al-Qust Al-Bahri (white roots of saussurealappa)". No published research studies are there to guide researchers, physicians and practitioners to the best anatomical sites for practicing Al-hijamah for treating different diseases as this science is still in its beginning and may benefit from future research. Based on our background in prophetic medicine, anatomy, medicine and our practice, we review here prophetic medicine, its remedies, cupping therapy of prophetic medicine (Al-hijamah), indications and anatomical sites that may be suitable for practicing Al-hijamah. Suitable anatomical sites for practicing Al-hijamah differ from disease to disease. In prophetic medicine, Al-hijamah was practiced at skin overlying and near sites of pathology e.g. skin overlying skull vertex, dorsal surface of the foot, thigh region and at general sites e.g. kahel region (mainly skin overlying $7^{\text {th }}$ cervical vertebra) and akhdayin (both sides of the neck posterior and inferior to ears and close to jugular veins. We report here a novel technique (Salah's technique) for practicing Al-hijamah safely at some special anatomical sites. In conclusion, Al-hijamah is better to be practiced at sites of pathology (for local clearance), at back region and back of neck (for general blood clearance).
\end{abstract}

Keywords: Cupping therapy; Al-hijamah; Prophetic medicine; Salah's technique; CPS; Pentad of cure of prophetic medicine

Abbreviations: AAGEPs- Advanced Glycation End Products; CPC method- Cupping, Puncturing and Cupping Method; CPC,WCTCupping, Puncturing and Cupping Method of Wet Cupping Therapy; CPS- Causative Pathological Substances; DM-Diabetes Mellitus; DCSDisease-causing Substances; DRS- Disease-related Substances; PC Method- Puncturing and Cupping Method; PCPM- Pentad of Cure of Prophetic Medicine; GIT-Gastrointestinal Tract; SS-Suction and Scarification Method (Double S Method); SSS-Suction, Scarification and Suction Method (Triple S Method, Al-hijamah); TCM-Traditional Chinese Medicine

\section{Introduction}

Cupping therapy is a simple, effective, economic and time-saving treatment. Different types of cupping therapy e.g. dry cupping therapy (DCT) and wet cupping therapy (WCT) are reported in traditional Chinese medicine (TCM) and are still practiced till now in China and in many parts of the world [1-3]. Contribution of TCM for herbal medicine and natural therapies deserves appraisal. TCM includes natural, simple and effective remedies e.g. cupping therapy. TCM improved the practice of cupping therapy to include many different subtypes e.g. weak/light cupping, medium cupping, strong cupping, moving cupping, needle cupping, moxa/hot needle cupping, empty/ flash cupping, full/bleeding cupping, herbal cupping and water cupping [1-3]. Cupping therapy is practiced officially in Chinese hospitals and gains attraction of researchers worldwide for its effective results in treating incurable chronic pain conditions [1-4]. In this review article, we will review cupping therapy of prophetic medicine (Al-hijamah), remedies in prophetic medicine, indications and anatomical sites for practicing prophetic Al-hijamah for treating different diseases.

*Corresponding author: Salah Mohamed El Sayed, Department of Medical Biochemistry, Sohag faculty of Medicine, Sohag University, Egypt, Tel: +2 0934-602-963; Fax: +2-0934-602-963; E-mail: salahfazara@yahoo.com, drsalahpediatr@yahoo.com

Received July 17, 2013; Accepted September 03, 2013; Published September 05, 2013

Citation: Mahmoud HS, Abou-El-Naga M, Omar NAA, El-Ghazzawy HA, Fathy YM, et al. (2013) Anatomical Sites for Practicing Wet Cupping Therapy (AlHijamah): In Light of Modern Medicine and Prophetic Medicine. Altern Integ Med 2: 138. doi:10.4172/2327-5162.1000138

Copyright: (c) 2013 Mahmoud HS, et al. This is an open-access article distributed under the terms of the Creative Commons Attribution License, which permits unrestricted use, distribution, and reproduction in any medium, provided the original author and source are credited. 


\section{Prophetic Sunnah and Prophetic Medicine}

Literally, sunnah means the way, method or style of life. Prophetic sunnah is the well-documented knowledge gained from prophetic hadeeths (sayings), deeds, advices and teachings in all aspects of life related to prophet Muhammad (Mohammad) peace be upon him [12,5-7]. Prophetic medicine is the medical aspect of prophetic sunnah and is related to health advices, preventive aspects and treatment of diseases. Prophetic medicine (in Arabic: Tib Nabawi) is defined as medicine related to Prophet Muhammad peace be upon him. Prophetic medicine dates back to the prophetic era in Makkah and Al-Madinah, two cities in Saudi Arabia (more than 1400 years ago) [1,2,5-7]. Prophetic medicine (related to Prophet Mohammad (Muhammad) peace upon him) recommends Al-hijamah (original cupping therapy of prophetic medicine) for treating many diseases and considered it as the best remedy $[1,2,5-7]$.

Prophetic medicine is an important source of human medicine (and medical knowledge) and is a heritage for the whole humanity. Allah (God) described Prophet Muhammad peace be upon him in the holy Qur'an (spoken word of Allah) as a mercy for humanity. Prophetic medicine needs more light to be shed on it. Recently, it was reported that knowledge gained from Qur'an (spoken word of God) and hadeeth enriched scientific research in Islamic civilization and supported advances in medicine, where medical treatment was encouraged in prophetic teachings $[5,8]$.

What seems miraculous regarding prophetic medicine is its exact agreement with today's modern scientific and medical knowledge taking into account that there was no modern scientific education or medical knowledge at era of the prophet peace be upon him (more than 1400 years ago) $[1,5-8]$.

In the Arab environment at prophetic era (more than 1400 years ago), there were no universities, medical conferences or medical schools. There was no contact with other physicians and there was no internet or telecommunications. Medical principles and practice changed wholly since that age and the new modern medicine replaced almost all the old medical knowledge [9-12]. Medicine taught and practiced during the era of Islamic civilization was a unity of the natural sciences and humanities under the umbrella of Islamic medical ethics $[8,13]$.

\section{Prophetic Medicine Remedies are Still Valid and up-to- date}

Although medical knowledge in the old great civilizations (Romans, Greek and Persian civilizations) at the same time of the prophetic era was more advanced than the Arab environment, many of the old remedies used for treating different diseases in those old civilizations are almost obsolete now and are replaced by modern medical and surgical treatment lines [9-12]. This is not the case as regard prophetic medicine, which is still valid until today. In agreement with modern medicine, prophetic medicine recommended treating different disease conditions through the use of Al-hijamah [1-2,5-7,14], honey [12,5-7,14], nigella sativa (black cumin)[15], costus(saussurealappa, costusspeciosus and others) [16], sucrose (in dates for infant

analgesia) [17-21], camel's milk and urine [22], talpinah(talbeenah, soup made from whole barley powder)[23], Ethmid(antimony) [24], kam'a (Terfeziaceae, desert truffles) [25], sana(senna, cassia angustifolia),sanut [26],

Zamzam water [27], dates of Madinah (ajwah of Aliahplanted in
Aliah region of Madinah) [28], teen (dust)of Al-Madinah [29], olive oil [30], miswak (siwak, teeth cleaning twigs made from a twig of the SalvadoraPersica) [31], henna (lawsoniainermis) [32] and others, Zamzam water [27], dates of Madinah (ajwah of Aliah) [28], teen (dust) of Al-Madinah [29], olive oil [30], miswak [31], henna [32] and others.

Later on, the golden age of the Arab civilization encouraged establishing universities and medical schools $[8,33]$. The term "Prophetic Medicine" was the name of the book written by the well-known moslim scholar Ibn Qayem Al-Jawzeyah who described (in Arabic) remedies of prophetic medicine for treating different diseases [6]. Another Arabic scholar, Al-Zahaby also wrote a book entitled (Prophetic Medicine) and described how the remedies mentioned in hadeeths and teachings of Prophet Mohammad peace be upon him relieved and cured patients with different diseases [7].

Generally, remedies in prophetic medicine are simple, safe, cheap, available, effective, valid and up-to-date. Al-hijamah (WCT of prophetic medicine) is among the best remedies according to the hadeeth (The best among what you use in therapy is Al-hijamah) [5,14]. Al-hijamah was referred to in a previous report as cupping, puncturing and cupping method (CPC) method of wet cupping therapy (CPC-WCT), which includes three major steps: cupping (suction of skin to create a skin uplifting), puncturing (scarification of skin uplifting) and cupping (suction of skin to excrete collected fluids mixed with some blood cells due to trauma of skin scarification) [1-2]. Al-hijamah may simply be referred to as suction, scarification and suction (SSS method or triple S) method. Taibah theory was recently suggested to explain medical and scientific bases of Al-hijamah [1-2] and explained possible therapeutic roles of Al-hijamah in treating diseases of different etiologies and pathogeneses in light of Taibah theory e.g. headache, fibromyalgia, carpal tunnel syndrome, hypertension, rheumatoid arthritis and pain conditions [1].

The prophet (peace be upon him) asked his nation to seek for medical treatment as every disease has a treatment: "for every disease, there is a treatment" [34].

Therapeutic aspects of Al-hijamah (CPC-WCT) aims at enhancing venous drainage at the skin related to diseased organ or tissue, which may lead indirectly to enhancement of arterial circulation at that diseased organ or tissue causing improved perfusion and improvement of body's response to pathology. According to Taibah theory, Al-hijamah aims also at causing a percutaneous non-specific pressure-dependent and size-dependent filtration then excretion of causative pathological substances (CPS) and accumulated metabolites in interstitial fluids and blood (in cutaneous blood capillaries) related to skin overlying diseased organ or tissue, which leads subsequently to clearance of causative factors of the disease pathogenesis. CPS include both disease-causing substances (DCS) and disease-related substances (DRS) arising during disease pathogenesis. Filtration of CPS occurs through pores and fenestrae of the fenestrated endothelium of skin capillaries [1].

Moreover, during Al-hijamah, a portion of the fluid component of blood (blood plasma) containing CPS, old hemolyzed blood cells, inflammatory interstitial exudate and any other soluble substances can be removed sparing the cellular components of blood i.e. preventive function of the triple $S$ technique. This decreases the amount of CPS and helps therapeutic effect of current pharmacological therapies [1].

\section{Scientific Rules of Practicing Al-hijamah}

Together with practicing Al-hijamah, medical consultation and 
treatment should be asked from specialized physicians where current pharmacological treatment should be given. In many disease conditions e.g. musculoskeletal pain conditions, Al-hijamah proved effective as a sole treatment. Al-hijamah was proved to be among the best treatment modalities to treat different diseases by itself or when combined with pharmacological treatments [1]. Al-hijamah should be regarded as strong, effective and curative treatment in itself and as a complementary and potentiating treatment to current medical and surgical treatment modalities. However, as Al-hijamah is a beneficial adjuvant preventive and therapeutic treatment during which blood and interstitial fluid are cleared, it has certain indications as any medical modality of treatment. This is the most important point to be considered.

Al-hijamah itself can be considered as a medical science (Hijamatology) to which scientific research should be directed to set up the standard way for gaining maximal therapeutic benefits from Al-hjamah. Hijamatology is a novel term describing the science related to education, knowledge, qualification, practice and research related to Al-hijamah. Hijamatologists are scientists and qualified practitioners working in Al-hijamah. Al-hijamah will synergize all medical treatment modalities as it will remove CPS (including DCS and DRS) that are targeted by medical treatment, which will facilitate better therapeutic outcomes and shorten the way towards cure. Being a non-pharmacological treatment, Al-hijamah is never antagonistic to any pharmacological treatment modalities as no chemical interaction will occur between Al-hijamah and therapeutics taken for different diseases, which will not disturb the therapeutic role exerted by different drugs. Whenever Al-hijamah is indicated or advised, it should be practiced by a qualified licensed practitioner (better to be a physician) in a well-equipped proper place (better in hospitals).

Al-hijamah (as an example of cupping therapy) is not working through opening or restoring energy sources (Qi) or opening energy channels as thought by some cupping practitioners because no published scientific evidence or report exists to support that. There is no anatomical or histological evidence to support that. This type of non-scientific thinking and interpretation for successful results of Al-hijamah or cupping therapy in treating certain diseases brought a big harm to the reputation of Al-hijamah [1]. Also, we disagree with some conceptions, which claim that female gives Yin (female $Q i$ ) and receives Yang (male $Q i$ ) while male gives Yang and receives Yin or the conception that both the Yin and Yang modalities of Q $i$ are actively present in all males and females [35] as there is no published scientific evidence or report to support that.

It was explained that cupping therapy can remove the wind, cold, dampness and stagnant blood, especially when cupping therapy was combined with acupuncture [36]. We disagree with that also.

Modern understanding of cupping therapy (in light of modern medicine and prophetic medicine) concludes that cupping therapy does not work through establishing the balance between positive and negative or Yin and Yang, which is against scientific thinking and has no medical background. Instead, Taibah theory for scientific mechanisms of cupping therapy is recently published as a novel evidence-based mechanism for explaining scientific and medical bases of cupping therapy [1].

Taibah theory explains on scientific bases how cupping therapy works through clearing blood plasma and interstitial fluids from CPS. Negative pressure introduced through sucking cups creates skin uplifting inside which interstitial fluids, filtered fluids from blood capillaries, hemolyzed blood cells (but no intact blood cells) and CPSare
I- For disease prevention (as a prophylactic measure)

II-Therapeutic indications

Musculoskeletal pain conditions (to excrete pain-causing substances,

mediators and cytokines) Knee osteoarthritis

Back pain and lumbar pain (lumbago)

Simple arthralgia, arthritis and musculoskeletal pain

Lumbar disc prolapse (as a nonsurgical treatment unless surgery is indicated)

Skeletal pain in general

Neck and shoulder pain

Cervical spondylosis and lumbar disc herniation

Persistent non-specific low back pain

Traumatic strain, sprain and post-

fracture conditions

Plantar fasciitis

b Cardiovascular diseases (to excrete excess intravascula

Hypertension (through excreting

excess serum fluids and vasoconstrictors)

pathology-related substances) Myocardial ischemia and arrhythmia Atherosclerosis

Some conditions of circulatory insufficiency

Vascular thrombosis (e.g. in the leg) Hypotension (through excreting excess serum vasodilators) (usually treated with fluids, steroids and vasoconstrictor drops)

Edema (to clear interstitial spaces from excess fluids)

Headache and Migraine

Carpal tunnel syndrome

Epilepsy

Early cerebral infarction

Brachialgia paraesthetica nocturna

Trigeminal neuralgia, trigeminal neuritis and facial neuritis

Laziness, lassitude and somnolence

Impaired memory or concentration

Some psychiatric conditions

Gastritis

Irritable bowel syndrome

Intoxication (toxin, food and drugs administration) (to clear blood from toxins)

e Respiratory and ENT diseases Bronchial asthma (to excrete pathology-related Motion sickness substances and enhance natural immunity)

\section{Tonsillitis}

Chronic sinusitis (antibiotic-resistant chronic sinusitis)

Otitis media

f Autoimmune diseases (to excrete excess autoantibodies immune complexes, cytokines prostaglandins, pathologyrelated substances and enhance natural immunity)
Rheumatoid arthritis

Vitiligo

Thyroid autoimmunity (Grave's disease and Hashimoto's thyroiditis)

Systemic lupus erythematosus Goodpasture's disease

Multiple sclerosis

Scleroderma

Addison's disease

Insulin-dependent diabetes mellitus 


\begin{tabular}{|c|c|c|}
\hline & & $\begin{array}{l}\text { Autoimmune anemia and pernicious } \\
\text { anemia }\end{array}$ \\
\hline & & Myasthenia Gravis \\
\hline & & Acanthosis Nigricans \\
\hline & & Ankylosing Spondylitis \\
\hline & & Cold Agglutinin Disease \\
\hline g & Metabolic conditions (to & Gout and gouty arthritis \\
\hline & excrete metabolites, waste & Thyroid dysfunction \\
\hline & substances, prostaglandins & Conditions of hormonal imbalance \\
\hline & $\begin{array}{l}\text { and pathology-related } \\
\text { substances) }\end{array}$ & $\begin{array}{l}\text { Hyperlipidemia and } \\
\text { hypercholesterolemia }\end{array}$ \\
\hline h & Infections (to excrete & Cellulitis \\
\hline & $\begin{array}{l}\text { causative pathogens, } \\
\text { metabolites, waste products, }\end{array}$ & $\begin{array}{l}\text { Some viral infections e.g. herpes } \\
\text { zoster }\end{array}$ \\
\hline & $\begin{array}{l}\text { patnology-related substances } \\
\text { and enhance natural immunity) }\end{array}$ & Viral hepatitis B and C \\
\hline & & Diabetic foot \\
\hline i & Hematological conditions & $\begin{array}{l}\text { Thalassemia (to excrete excess iron } \\
\text { and fragmented cells) }\end{array}$ \\
\hline & & $\begin{array}{l}\text { Sideroblastic anemia (to excrete } \\
\text { excess iron) }\end{array}$ \\
\hline & & $\begin{array}{l}\text { Hemosiderosis and hemochromatosis } \\
\text { (to excrete excess iron) }\end{array}$ \\
\hline & & $\begin{array}{l}\text { Hemolysis (to excrete liberated } \\
\text { hemoglobin and fragmented cells) }\end{array}$ \\
\hline & & $\begin{array}{l}\text { Hemolysis (to excrete liberated } \\
\text { hemoglobin and fragmented cells) }\end{array}$ \\
\hline j & Miscellaneous (to excrete & Conditions of impaired immunity \\
\hline & pathology-related substances & Alopecia \\
\hline & & Chronic fatigue syndrome \\
\hline & & Glaucoma \\
\hline & & Pain of dysmenorrhea \\
\hline & & $\begin{array}{l}\text { Some ovulatory disorders (cause of } \\
\text { female infertility, which may be due } \\
\text { hyperestrogenemia) }\end{array}$ \\
\hline & & $\begin{array}{l}\text { Errors of metabolism (to clear blood } \\
\text { from accumulated substrates and } \\
\text { metabolites) }\end{array}$ \\
\hline
\end{tabular}

Table 1: Preventive and therapeutic indications of Al-hijamah.

collected just beneath skin barrier inside skin uplifting. Upon scarifying skin uplifting superficially and applying $2^{\text {nd }}$ suction step using cups, all collected fluids are excreted mixed with some blood cells that come out from traumatized capillaries. Further capillary blood clearance occurs with further removal of CPS from capillary blood. During the process of Al-hijamah, excretory skin functions are enhanced, congestion is removed, tissue adhesions are broken and homeostasis is restored [1].

\section{Indications of Al-hijamah}

Based on Taibah theory, indications for Al-hijamah include treating diseases that will benefit maximally or partially from clearing blood and interstitial spaces from CPS through excreting excess intravascular fluids, excess interstitial tissue fluids and excretion of other CPS while taking into account the other health-based benefits of Al-hijamah (Table 1). An example for increased extracellular and interstitial fluid volume is hypertension [37] that was reported to improve on WCT [38] as fluid overload was reported to play an important role in the pathogenesis and development of salt-dependent hypertension [39]. An example for toxic CPS in interstitial fluids is cellulitis. Cellulitis is a local form of suppurative inflammation of the skin and underlying tissues with an accompanying increase in inflammatory tissue fluids (exudate) together with increased CPS in the form of bacteria and bacterial toxins (CPS) [40-42]. Cellulitis was reported to improve on using WCT $[1,43]$.
An example for increased inflammatory CPS is chronic osteoarthritis. Chronic osteoarthritis is a chronic inflammatory process initiated by proinflammatory cytokines e.g. interleukin-1 and tumor necrosis factor-1 alpha together with an acceleration of cartilage degradation process through increased levels of matrix metalloproteinases, stromelysins, gelatinase and plasminogen activators [44]. All those CPS are catalyzing the pathogenesis of osteoarthritis. Al-hijamah-induced clearance of those CPS from blood plasma and interstitial fluids may explain on scientific bases the improvement reported by chronic osteoarthritis patients upon treatment with Al-hijamah.

\section{Anatomical Sites for Practicing Al-hijamah}

As a repeated question asked to hijamatologists by many practitioners and patients: what are the most suitable skin sites for applying sucking cups during Al-hijamah therapy? Is there any scientific bases underlying specifying those sites? Do those sites differ from disease to disease? Do therapeutic outcomes change on using different sites?

In fact, little published research exists to answer such questions but the answers can be gained based on understanding Al-hijamah in light of modern medicine and prophetic medicine. Basically speaking, diseases that will benefit from Al-hijamah are diseases in which their pathogenesis may be characterized by excess tissue fluids (transudates or exudates), intravascular fluids or CPS. As a general guide when putting sucking cups during Al-hijamah, it is better to be as near anatomically as possible to the diseased tissue to facilitate excretion of CPS. Taking cellulitis as a proved example of excreting bacterial toxins and bacteria in cupped blood [43], WCT done over the inflamed cellulitis region dramatically relieved the inflammatory and toxic processes through excreting bacteria and bacterial toxins in cupped blood in addition to sucking edema fluid (inflammatory exudate). Based on Taibah theory [1], when the pathology or disease process occurs in a viscus or organ that is not near the skin surface e.g. headache and migraine [45], blood clearance can be done -as we learnt from prophetic medicineby applying sucking cups to head regions, kahel region and akhdayin regions as we will discuss later. Answering previously asked questions implies that specifying anatomical sites that differ from disease to disease is important according to anatomical sites of pathology and the required degree of clearance of blood and interstitial spaces. Scientific bases for selecting specific anatomical sites when treating pathological conditions using Al-hijamah (as we learn from prophetic medicine) depends on the primary site of pathology and its distribution and the degree of therapeutic benefits gained from blood and interstitial fluid clearance as we will explain below. The degree of blood clearance can be enhanced by increasing the number, size and pressure (to a certain extent) of cups. Optimization of Al-hijamah-induced therapeutic clearance will differ when changing the sites of cups application or the number of cups. This urged us to write this article to benefit practice and research in hijamatology.

\section{Scientific bases Beyond Selecting Anatomical Sites for Practicing Al-hijamah in Prophetic Medicine}

In prophetic medicine, we review here that prophet Muhammad peace be upon him asked for Al-hijamah in kahel region (mainly skin over $7^{\text {th }}$ cervical vertebral spine and may expand to include surrounding skin area and interscapular region) [46], Akhdayin (skin overlying both sides of the neck behind the ears) [46], in between the 2 scapulae, on the head region (after shaving hair) [47], on the center of the head (skull 
vertex after shaving hair) [48], on the yafokh region (In the middle of the upper part of the vault of the skull) [49], on the thigh region [50,51] and on the dorsal surface of the foot [52]. The indications for performing prophetic Al-hijamah were to treat more than one disease condition, which supports the fact that Al-hijamah can benefit in treating more than one disease with variable etiologies and pathogeneses through non-specific excretion of CPS of each disease [1-2]. As a general rule, shaving hair in the area to be cupped ensures a perfect sterile atmosphere with no liability of existence of hair (foreign body) at skin puncture sites, which is expected to facilitate easy rapid healing of skin scarifications done in the process of Al-hijamah.

\section{Indications for Prophetic Al-hijamah}

We review here that in prophetic medicine, Al-hijamah (as a prophetic teaching) was asked by the prophet peace be upon him for treating different disease conditions. Al-hijamah was done at head region for treating headache and migraine [53] and was done at dorsum of foot [52] and at thigh region [51] for treating traumatic pain (may be due to strain or sprain). Prophetic Al-hijamah was done at sites of pain. Therapeutic benefits beyond clearance of blood and interstitial spaces in treating headache may occur through excretion of noxious substances related to to pathogenesis of headache and migraine. Those noxious CPS may include high serum brain derived neurotrophic factor [54], high serum transforming growth factor $\beta 1$, C-reactive protein [55], excess serum fluids, chemical mediators, Il-6, vasoactive substances, neuropeptides causing headache $[38,56]$ e.g. substance $P$, vasoactive intestinal polypeptide and calcitonin gene-related peptide that are important mediators in the pathogenesis of migraine and other primary headaches [56]. Al-hijamah may decrease interstitial fluid pressure and may treat predisposing factors for headache e.g. hypertension $[1,38]$ and acute trigeminal neuralgia $[1,2,57]$. Common traumatic injuries at thigh region include strain, contusion and avulsion, which are characterized by hematoma at the musculotendinous junction, perifascial blood or haematoma, intramuscular hemorrhagic dissection and muscle fiber disruption [58]. Al-hijamah done at site of trauma may be beneficial in draining painful exudate collected locally in interstitial spaces at the site of trauma. It is reported that musculoskeletal infection is a common finding during trauma in emergency department affecting various soft-tissue layers, bones, and joints. Infection may present as necrotizing or non-necrotizing fasciitis, superficial cellulitis, myositis, soft-tissue abscess, osteomyelitis or septic arthritis [59].

Hematoma due to limb trauma may occur in rare cases and may progress to chronic expanding hematomas that are tumor-like lesions with a vague history of trauma that usually lays dormant for many months before suddenly starting to expand in a mode very similar to that of a chronic subdural haematoma [60]. The importance of these swellings lies in its mimicry to soft tissue sarcomas, dystrophic calcification (associated with reactive inflammatory changes), calcific myonecrosis, chronic expanding hematoma and post-traumatic cyst of soft tissues, which may rarely complicate such traumatic hematoma [60-62].

Based on modern understanding of how Al-hijamah works (Taibah theory), Al-hijamah may drain CPS [1] at trauma site e.g. hematoma, pain mediators, wound exudate, pus and inflammatory substances. Drainage of a localized hematoma may benefit in preventing its secondary bacterial infection or future calcification. Al-hijamah benefits patients having trauma through endogenous opioid production causing pain relief [1-2].

Interestingly, it was reported that whenever Prophet Muhammad peace be upon him was consulted for treatment of headache, he advised using Al-hijamah and when he was consulted for treating pain in legs, he advised using decoration with henna [63].

\section{Lessons Gained from Anatomical Sites of Al-hijamah in Prophetic Medicine}

The first lesson is to practice Al-hijamah at sites of pathology e.g. to put sucking cups on head regions when treating headache and migraine and at limb regions over painful sites in case of trauma and so on.

Second lesson learnt from prophetic medicine is to practice Alhijamahas soon as possible to get the maximal therapeutic benefit and to do Al-hijamah even during travel before reaching target destination (i.e. the sooner the better) e.g. during fasting or pilgrimage travel. It is also gained from prophetic medicine to practice Al-hijamah at Kahel region ((mainly skin over $7^{\text {th }}$ cervical vertebral spine and may expand to include surrounding skin area and interscapular region) and at back sites of the neck. The most safe and suitable skin points are the back region as this region is a hidden area (from the cosmetic point of view), having a large flat surface area (easy to apply sucking cups), away from critical structures (nerves and vessels) and is more comfortable to the patient. Prophetic medicine was our reference in selecting back points e.g. the Kahel region seems to be the most suitable point for practicing Al-hijamah for therapeutic and preventive purposes and is regarded as a common place for clearing blood coming to the skin circulation in treating many disease conditions. Kahel region is a prominent anatomical landmark and its surface marking is easy to be detected on the midline of the back at the junction of the back of the neck with the back region. Other related positions can be defined as above kahel region, below kahel region, to the right of kahel region and to the left of it. Prophet Mohammad peace be upon him asked the physician to do Al-hijamah for him at many sites for treating different diseases in which anatomical sites for practicing Al-hijamah changed from disease to disease.

Third lesson is to practice WCT not DCT as steps of Al-hjamah include all steps and health benefits of both DCT and WCT altogether (Taibah theory) [1]. Mere DCT is not therapeutically curative as no excretion of CPS or blood clearance occur in DCT $[1,2]$.

Fourth lesson is to practice Al-hijamah (Triple S technique, CPCWCT) not Chinese WCT (Double S technique, PC-WCT) as more

\begin{tabular}{|l|l|}
\hline Critical anatomical sites & Critical due to presence of: \\
\hline $\begin{array}{l}\text { 1. Skin overlying carpal tunnel in } \\
\text { carpal tunnel syndrome (frontal } \\
\text { aspects of the lower part of forearm). }\end{array}$ & $\begin{array}{l}\text { Subcutaneous structures e.g. nerves } \\
\text { (median nerve in carpal tunnel) and } \\
\text { superficial veins }\end{array}$ \\
\hline $\begin{array}{l}\text { 2.Skin overlying the thyroid gland in } \\
\text { thyrotoxicosis }\end{array}$ & $\begin{array}{l}\text { Superficial veins and being near course of } \\
\text { great vessels }\end{array}$ \\
\hline 3.Hairy skin in axilla & $\begin{array}{l}\text { Brachial plexus (nerve supply of upper } \\
\text { limb) }\end{array}$ \\
\hline 4. Skin overlying nasal sinuses & $\begin{array}{l}\text { Dangerous area of the face (possibility } \\
\text { of transmission of infection to intracranial } \\
\text { structures) and possibility of forming scars } \\
\text { (cupping malpractice) }\end{array}$ \\
\hline 5.Skin just in front of ears & $\begin{array}{l}\text { Exit of facial nerve from stylomastoid } \\
\text { foramen in front of ears }\end{array}$ \\
\hline 6.Dangerous triangle of the face & $\begin{array}{l}\text { Very near anatomically to dural sinuses } \\
\text { (may help transmission of infection to } \\
\text { intracranial structures) and possibility of } \\
\text { skin scarring. }\end{array}$ \\
\hline $\begin{array}{l}\text { 7. Points at course of neck veins, } \\
\text { superficial temporal arteries or any } \\
\text { superficial veins. }\end{array}$ & Possibility of hemorrhage \\
\hline
\end{tabular}

Table 2: Special (critical) anatomical sites for practicing Al-hijamah. 
therapeutic benefits are gained through Al-hijamah via better clearance of blood and interstitial fluids from CPS [1].

Fifth lesson is to use manual suction method (moderate degree of suction pressure) not alcohol or flame suctions (higher degrees of suction pressure) [64], which may exert very high suction pressure that may damage capillaries and disturb the process of filtration and cause bloodletting instead. Manual suction is more reproducible than both flame and alcohol suction methods [64].

Sixth lesson is also based on understanding anatomical sites mentioned in prophetic medicine where anatomical sites for practicing Al-hijamah can be categorized into local and general anatomical sites. Local anatomical sites (overlying site of pathology and/or complaint) may be better for clearing interstitial fluids, interstitial spaces, lymphatic fluids, exudates and edematous sites. They are also better for resolving local pathology by excreting local fluid collections and CPS. General sites for practicing Al-hijamah (e.g. kahel region, some back points and akhdayin regions) may be better for clearing blood from any CPS (general sites are rich in blood supply and have a large flat surface area for application of more cups) but may be less effective than local sites for local tissue clearance.

\section{Al-hijamah at the Special Anatomical Areas}

The majority of anatomical points to which sucking cups should be applied are safe with no technical problems during performing Alhijamah. Anatomically, special areas of the body are few anatomical sites where superficial critical structures e.g. arteries, nerves and veins pass subcutaneously and may be injured during skin scarification step of Al-hijamah (Table 2). Dangerous anatomical area of the face is a triangular area bordered by the upper lip (lateral angles of the mouth on both sides) and the upper part of the nose.

It is advisable to avoid practicing Al-hijamah at critical anatomical sites unless necessary. Necessity is decided when improvement is not likely to occur without practicing Al-hijamah at those sites. Fortunately, most anatomical sites for practicing Al-hijamah are safe with no important subcutaneous structures. This note is very important, especially for beginners to ensure safety of practice. Whenever it is strongly indicated to practice Al-hijamah at such anatomical sites, it is a must to avoid performing Al-hijamah at the dangerous area of the face as a routine. It should only be practiced in rare highly indicated exceptional cases to avoid injuring critical structures. Al-hijamah on the face should never be practiced as a routine to minimize possibility of skin scarring or transmission of infection to intracranial structures. It is a must to select the most experienced, most senior, highly skillful and most knowledgeable practitioner to perform Al-hijamah at these sites. The patient to whom facial Al-hijamah will be performed should give a written consent.

It is a must to know and revise the detailed anatomy of the dangerous area of the face every time before practicing Al-hijamah. It is a must to feel and locate the course of superficial arteries, veins and nerves and to do the most superficial skin scarifications away from their anatomical course. Application of Salah's technique for safe practice of Al-hijamah at special anatomical sites is advisable.

\section{Salah's Technique for Safe Practice of Al-hijamah at Special Anatomical Sites}

This is a novel technique (named after author's name) aiming at gaining maximal and safe therapeutic benefit of practicing Al-hijamah (skin scarification step) at skin overlying sites of pathology in special anatomical areas (Table 2) e.g. skin overlying carpal tunnel in carpal tunnel syndrome, skin overlying the thyroid gland in thyrotoxicosis and skin overlying nasal sinuses in antibiotic-resistant severe cases of chronic sinusitis. First ensure that local hair is shaved and the local area is sterilized many times. The technique is preceded by $1^{\text {st }}$ cupping (suction) step for few minutes and is followed by $2^{\text {nd }}$ cupping (suction) step.

When doing skin scarifications, touch not cut the skin using a new sterile scalpel under proper illumination in a strictly sterile medical environment (wearing sterile gloves). The technique simply implies pinching a small fold of skin carefully between thumb and index fingers of the left hand, while the right hand scarifies the skin fold with few small superficial scarifications (about $0.1 \mathrm{~mm}$ in depth just to open skin barrier that is horny cell layer of the epidermis) then another skin fold is pinched out and so on. Selected pinched skin folds must be taken from the cupped area. Care must be taken not to include any anatomical structure (nerve or a superficial vein) inside the pinched skin fold and this is easily done by pinching a small skin area from the skin surface. Scarifications must be so superficial not deep, sequential not simultaneous, few not many, vertical not transverse, longitudinal not pin-point, short (about $2 \mathrm{~mm}$ ) not long and gently slow not rapidly done.

Importance of this technique is that it allows gaining maximal therapeutic benefit from practicing Al-hijamah at skin sites directly overlying pathology, which is expected to give better local clearance of interstitial fluids and improvement of pathology than practicing Alhijamah at distant anatomical sites. Moreover, $1^{\text {st }}$ and $2^{\text {nd }}$ suction steps may benefit so much in relieving compression upon vital structures e.g. may relieve compression upon median nerve in carpal tunnel syndrome.

\section{Anatomical Sites for Treating Different Diseases using Al-hijamah (Tables 3 and 4)}

From the practical point of view, it is an important science to locate the most suitable anatomical sites for applying sucking cups to treat different diseases using CPC-WCT (Al-hijamah). Unfortunately, no published research work or medical study is there to compare different anatomical sites to guide us to the most suitable anatomical points to treat different diseases using Al-hijamah. In fact, hijamatology is an important science to which more extensive research should be directed to enrich this science with modern medical benefits. Ahmed Hefny was the first scientist and practitioner hijamatologist to locate and write about the best anatomical sites for applying sucking cups when treating different diseases using Al-hijamah. Ahmed Hefny mentioned the anatomical sites for practicing Al-hijamah based on his knowledge in prophetic medicine, TCM and the satisfactory results he got on performing Al-hijamah at those sites for treating different diseases [65]. Anatomical points mentioned by Ahmed Hefny were in head and neck region (Table 3a) (Figure 1), [66-69] frontal aspect of chest, abdomen and pelvis (Table 3b) (Figure 2) [67,70], back of trunk (Table 3c) (Figure 3) $[66,71]$ and limbs (Table 3d) (Figure 4) [72-76]. Ahmed Hefny was pioneering as there was no previous published research or report in this field of hijamatology. Anatomical sites reported by Ahmed Hefny are the fruit of studying anatomical sites reported in prophetic Al-hijamah in prophetic medicine, anatomical sites for practicing acupuncture and Chinese cupping therapy in TCM and related books written by international practitioners of acupuncture and cupping therapy from different countries e.g. Japan, Germany, Australia and others. 
Citation: Mahmoud HS, Abou-El-Naga M, Omar NAA, El-Ghazzawy HA, Fathy YM, et al. (2013) Anatomical Sites for Practicing Wet Cupping Therapy (Al-Hijamah): In Light of Modern Medicine and Prophetic Medicine. Altern Integ Med 2: 138. doi:10.4172/2327-5162.1000138

Future research and publications will help a lot to establish and optimize the best anatomical sites for practicing Al-hijamah. ElGhazzawy reported also anatomical sites for practicing Al-hijamah based on background in prophetic medicine and TCM practice [77]. Rafeek Tib Nabawi (RTN, companion of prophetic medicine) anatomical sites were recently reported by Hany Salah as novel anatomical sites (Table 3e) (Figures 1-4) added to the anatomical sites originally reported by Ahmed Hefny [65]. Until now, it is a matter of optimizing the results of Al-hijamah practice and experience at the well-known anatomical sites for applying sucking cups and this is liable to future modifications in light of future research [78].

The golden rules when selecting anatomical sites for practicing Al-hijamah is to put sucking cups on the skin overlying the diseased tissue e.g. putting sucking cups over inflamed skin in cellulitis. This will facilitate clearing interstitial fluids and blood capillaries from CPS in this anatomical area. Second choice is to place sucking cups at the nearest possible skin area to the site of pathology e.g. putting sucking

\section{Region number Anatomical sites and surface marking [65,77]}

2 and 3

(Para-akhdayin

regions)

32 (yafokh region) About $14 \mathrm{~cm}$ above posterior hair line at the midpoint of an imaginary line connecting both auricles. In the middle of the upper part of the vault of At skin overlying the spinous process of $7^{\text {th }}$ cervical vertebra. It is the most prominent vertebral spine at the lower aspect of back of the neck.

To the right and left of both sides of the attachment of both sternocleidomastoids to the cleinoid process in the back of the cranium. On the back of both ears (safe and easy for practicing Al-hijamah at the back of neck and suitable for practicing Al-hijamah in females being non-hairy regions)

the skull

33 Immediately to the right of region \#32

\begin{tabular}{l|l}
34 and 35 & To the far right and left of region \#32 on the vault of the skull (both overly the skin overlying the part of the cranium above right and left cerebral
\end{tabular} hemispheres, respectively). At the external occipital protuberance. At skin overlying a point below the middle of the occipital bone (overlying part of cranium above cerebellum and brain stem)

37 and $38 \quad$ Above the 2 ears by about $3 \mathrm{~cm}$

$39 \quad$ At the back of the cranium at the inserti in the middle of the posterior hairline)

40 At the lower part of the midline of the back of the neck (below region \# 39 and above region \#1)

41 and $42 \quad$ On both sides of region \#40 at the back of the neck

43 and 44 (Regions On both sides of the neck behind and below both ears and related to course of jugular veins

of Akhdayin) N.B. Both are special anatomical sites necessitating the use of Salah's technique.

$101 \quad$ Upper part of forehead (within the anterior hair line).

102 and $103 \quad$ Above and medial to both eyebrows

104 and $105 \quad$ Lateral to both eyes

$106 \quad 6 \mathrm{~cm}$ above left ear

107 At the right corner of the forehead (about $1 \mathrm{~cm}$ inside hair line at the right corner of the forehead)

108 and $109 \quad$ On both sides of the nose (Above the alae nasai)

110 One finger breadth anterior and superior to the inferior angle of the mandible

$111 \quad$ Below region \#104

$112 \quad$ Below the infraorbital foramen (about $6 \mathrm{~cm}$ lateral to the left ala nasai)

$113 \quad$ Lateral to the left angle of the mouth

$114 \quad$ Below the chin

Table 3a: Anatomical sites for practicing Al-hijamah in head and neck region (Figure 1).

Region number Anatomical site and surface marking [65,77]

115 and 116 Represented by 2 point is in the middle of the frontal aspect of deltoid muscles when the arm is fully abducted. N.B. Some authors describe those 2 points to be at left and right shoulders to the outside of the lateral ends of both clavicles.

117 and $118 \quad$ Below the left and right sterno-clavicular joints, i.e. below the lower medial borders of both clavicles (about $4 \mathrm{~cm}$ lateral to the midline)

119 About 4 finger breadths below the middle part of the left clavicle (inferolateral to region \#117).

$120 \quad$ At middle (midpoint) of the sternum (facing position \#49 on the back)

$121 \quad$ Just below the xiphoid process at the midline of the abdomen

122 Below and lateral (to right side) to region \#121. A point at $6^{\text {th }}$ intercostal space about $5 \mathrm{~cm}$ from midline (about 2 ribs below the nipple)

$123 \quad$ About $3 \mathrm{~cm}$ below region \#122.

$124 \quad$ About $4 \mathrm{~cm}$ below and lateral to region \#123

125 and 126 Directly above the inguinal groove (above and lateral to felt pulsation of femoral artery) N.B. Special care should be taken when performing Al-hijamah at these regions using Salah's technique.

$133 \quad$ Upper part of skin overlying the epigastrium in front of xiphisternum

$134 \quad$ Below left breast (about $10 \mathrm{~cm}$ lateral (to the left) to region \#121 in the midclavicular line)

135 and $136 \quad$ In left and right $4^{\text {th }}$ intercostal spaces $(4 \mathrm{~cm}$ from midline) i.e. just above and lateral to region \#133

$137 \quad$ At the midline of the abdomen ( $4 \mathrm{~cm}$ above the umbilicus)

138, $139 \quad$ About $4 \mathrm{~cm}$ to the left and right sides of the umbilicus

140 At the midline of the abdomen ( $3 \mathrm{~cm}$ below the umbilicus)

141 and 142 Below the umbilicus on the left and right sides of region \#140 (about 4cm from midline)

143 At the midline of the abdomen just above symphysis pubis

Table 3b: Anatomical sites for practicing Al-hijamah in the ventral aspect of the chest and abdomen (Figure 2) 


\begin{tabular}{|c|c|}
\hline Region number & $\begin{array}{l}\text { Anatomical site and surface marking } \\
{[67,68]}\end{array}$ \\
\hline 4 and 5 & In between the upper part of the medial borders of the 2 scapulae i.e. about $3 \mathrm{~cm}$ lateral to the spinous process of $3^{\text {rd }}$ thoracic vertebra. \\
\hline 6 & Over the medial aspect of the right scapula (lateral to the lower border of spinous process of the 10th thoracic vertebra). \\
\hline 7 and 8 & In the middle of the back on both sides of the vertebral column i.e. lateral to the lower border of the spinous process of the $12^{\text {th }}$ thoracic vertebra). \\
\hline 9 and 10 & Below 7and 8 points (lateral to the lower border of the spinous process of the $2^{\text {nd }}$ lumbar vertebra). \\
\hline 11 & In between $4^{\text {th }}$ and $5^{\text {th }}$ lumbar vertebrae (lower part of the back). \\
\hline 12 and13 & Slightly higher and on both sides of position no. 11 by about $6 \mathrm{~cm}$ \\
\hline 14 & Below and lateral to region \#9 \\
\hline 15 & Below and lateral to region \#10 \\
\hline 16 & Slightly above and lateral to region \#12 \\
\hline 17 & Slightly above and lateral to region \#13 \\
\hline 18 & Slightly above region \#11 \\
\hline 19 & On the back side of the left scapula about (below and lateral to region \#5) \\
\hline 20 and 21 & At midpoints of skin covering trapezii. These points are beneficial in treating neck pain, shoulder pain and tingling of upper limbs. \\
\hline 22 and 23 & About $6 \mathrm{~cm}$ lateral to the lower border of the $7^{\text {th }}$ thoracic spinous process at the level of the inferior angle of the scapula. \\
\hline 24 and 25 & In the upper part of the lower half of the back (above and lateral to region \#18). \\
\hline 26 & Below and lateral to region \#16 \\
\hline 27 & Below and lateral to region \#17 \\
\hline $\begin{array}{l}28,29,30 \\
\text { and } 31\end{array}$ & $\begin{array}{l}\text { Represented by a line across the upper part of both right and left buttocks on the back of the pelvis. Points } 28 \text { and } 31 \text { are present at skin overlying the } \\
\text { outer posterior aspect of the iliac crest }\end{array}$ \\
\hline 45 and 46 & On both sides of region \#55 \\
\hline 47 & Skin overlying back of left shoulder \\
\hline 48 & Above and lateral to region \#4 \\
\hline 49 & Below the spinous process of the $6^{\text {th }}$ thoracic vertebra ( below and medial to region $\# 5$ in the midline of the back in between the 2 scapulae) \\
\hline 50 & Lateral to region \#23 (About $6 \mathrm{~cm}$ above and to the left of region \#8) \\
\hline 51 & Below and lateral to region $\# 28$ on lateral pelvic aspect \\
\hline 52 & Below and lateral to region \#31 on lateral pelvic aspect \\
\hline 55 & Below region \#1 \\
\hline
\end{tabular}

Table 3c: Anatomical sites for practicing Al-hijamah in the back region (back of the trunk) (Figure 3).

\begin{tabular}{|l|l|}
\hline Region number & Anatomical site and surface marking $[\mathbf{6 5 , 7 7 ]}$ \\
\hline 53 and 54 & Dorsal surface of knee joint \\
\hline 129 & Dorsal surface of foot \\
\hline 130 & On both sides of lower part of tendo-achilis \\
\hline 131 & About $5 \mathrm{~cm}$ above calcaneous bone (above region \#132) \\
\hline 132 & At the lower half of tendo-achilis (above region \#130) \\
\hline
\end{tabular}

Table 3d: Anatomical sites for practicing Al-hijamah in the upper and lower limbs (Figure 4).

cups over head sites in treatment of headache and migraine. This may help to a certain extent in clearing interstitial fluids and blood capillaries from CPS [1]. Third choice is to locate sucking cups at the skin areas supplied by the same cutaneous innervation (same dermatome as the site of pathology) e.g. putting sucking cups over skin of left shoulder (same dermatomal nerve supply with heart) on treating myocardial ischemia. This may decrease the pain intensity in the diseased tissue or viscus by making use of the nervous pathways for referred pain (pain that arises in an organ and is felt in a distant place usually a skin area with the same dermatome).

The areas in the back as kahel region (regions \#1 and 55) and between the 2 scapulae are common sites for treating most diseases. These areas are mentioned originally in prophetic medicine. The reason seems that those points are in the skin of the back and are easily accessible in the flat surface of the back and are at hidden sites, which will not constitute a cosmetic problem due to ecchymosis or possible scars (in case of cupping malpractice). Back points are easy for fixing sucking cups, scarifying the skin and applying as many sucking cups as desired. Back points are related to skin beneath which exists the posterior abdominal wall but no critical structures or superficial blood vessels leading to absence of risk of massive bleeding on scarifying skin. Back points can accommodate large-sized cups that add more clearing effect during Al-hijamah. Moreover, in the same time, back points are the most suitable anatomically for treating pain related to spine. This includes pain of the back of the neck, pain in the lumbar region (lumbago) and pain in the low back region. Applying sucking cups to the back regions will benefit in breaking adhesions, relieving congestion and correcting musculoskeletal pain. Back points can allow putting many suction cups, which allow clearing blood at multiple different anatomical points leading to better clearance of blood and interstitial fluids.

For all that, back regions are recommended for practicing Alhijamah for preventive purposes, therapeutic purposes and for practicing Al-hijamah as a routine practice (Tables 3 and 4 ). Back regions are also indicated as adjuvants for practicing Al-hijamah in treating so many diseases of different etiologies and pathogeneses in which more clearance of interstitial spaces and blood will help in treating or curing the underlying pathology. Patient should receive regular medical and or surgical treatments prior to or simultaneously with Al-hijamah therapy. Table 1 lists some disease conditions in which Al-hijamah may be beneficial (degree of benefit varies from improving symptomatology to cure), while table 3 mentions the most suitable anatomical sites when treating such diseases using Al-hijamah. Table 4a-4j lists anatomical sites for applying cups for Al-hijamah for preventive purposes. Table 4 also lists some diseases that may benefit from treatment using $\mathrm{Al}$ hijamah and the anatomical sites for cups application (Figures 5-12).

As a golden rule, Al-hijamah should be done at as many anatomical points as the patient can tolerate to ensure better local and systemic 
Citation: Mahmoud HS, Abou-El-Naga M, Omar NAA, El-Ghazzawy HA, Fathy YM, et al. (2013) Anatomical Sites for Practicing Wet Cupping Therapy (Al-Hijamah): In Light of Modern Medicine and Prophetic Medicine. Altern Integ Med 2: 138. doi:10.4172/2327-5162.1000138

\section{RTN sites [78] Anatomical location}

RTN 1 In between the 2 scapulae (on the left of the midline of the back)

RTN 2 In between the 2 scapulae (on the right of the midline of the back)

RTN $3 \quad$ Just above the patella of the knee joint (on both sides)

RTN $4 \quad$ Below and medial to RTN 6 (medial to middle part of the patella of the knee joint) (on both sides)

RTN $5 \quad$ Below and lateral to RTN 7(lateral to middle part of the patella of the knee joint) (on both sides)

RTN $6 \quad$ Below and medial to RTN 3 (medial to upper part of the patella of the knee joint) (on both sides)

RTN 7 Below and lateral to RTN 3 (lateral to upper part of the patella of the knee joint) (on both sides)

RTN 8 Below RTN 4 (medial to lower part of the patella of the knee joint) (on both sides)

RTN $9 \quad$ Below RTN 5 (lateral to lower part of the patella of the knee joint) (on both sides)

RTN $10 \quad$ Midline of the back (above gluteal region by about $6 \mathrm{~cm}$ i.e. above region \#11)

RTN $11 \quad$ To the right of RTN 10 (immediately above region \#12)

RTN 12 To the left of RTN 10 (immediately above region \#13)

RTN $13 \quad$ Midline of the back just above RTN 10

\begin{tabular}{l|l} 
RTN 14 & To the right of RTN 13
\end{tabular}

RTN $15 \quad$ To the left of RTN 13 (immediately above RTN12)

RTN $16 \quad$ Upper part of the head on the coronal suture (at the meeting of the frontal bone with occipital bone)

RTN 17 Above RTN 18 and directly to the right of RTN 19

RTN $18 \quad$ Above and to the right of the sacroiliac joint

RTN 19 At the midline of the back (about $6 \mathrm{~cm}$ above the sacroiliac joint)

RTN $20 \quad$ Directly to the left of RTN 19

RTN $21 \quad$ Below RTN 20 (above and to the left of the sacroiliac joint i.e. corresponding to RTN 18)

RTN $22 \quad$ At sternal notch

RTN 23 Below and to the left of the thyroid cartilage.

N.B. This is a special anatomical area that should be taken with extreme care using Salah's technique.

RTN $24 \quad$ To the left of thyroid cartilage.

N.B. This is a special anatomical area that should be taken with extreme care using Salah's technique.

RTN $25 \quad$ To the right of thyroid cartilage.

N.B. This is a special anatomical area that should be taken with extreme care using Salah's technique.

RTN 26 Below RTN 25

RTN $27 \quad$ Region of the upper part of left cheek (left side of the face) in front of left auricle (below region \#111) N.B. This is a special anatomical area (exit of facial nerve) that should be taken with extreme care using Salah's technique.

RTN 28 Corresponding to RTN 27 on the right side i.e. Region of the upper part of right cheek (right side of the face) in front of right auricle. N.B. This is a special anatomical area (exit of facial nerve) that should be taken with extreme care using Salah's technique.

RTN 29 The whole medial and lateral aspects of the leg and the foot in addition to the dorsum of the foot (excluding back of leg and plantar aspect of foot)

RTN 30 Medial part of the right costal region attached to the lower end of the sternum.

RTN $31 \quad$ Below and lateral to RTN 30

RTN 32 Lower lateral part of the right costal region attached to the lower end of the sternum (lateral and superior to RTN 31)

RTN $33 \quad$ Below RTN 31

RTN $34 \quad$ Middle part of right costal region attached to the lower end of the sternum (on the anterior abdominal wall i.e. slightly below and lateral to RTN31 at a portion of the skin region overlying liver)

RTN $35 \quad$ Slightly below and lateral to RTN 33

RTN 36 At the hairy axillary region (skin overlying the axilla and frontal aspect of posterior axillary fold).

N.B. This is a special anatomical area below which brachial plexus is present. It should be taken with extreme care using Salah's technique.

RTN 37 At the umbilical region (umbilicus should be in the center of the cup during Al-Hijamah)

RTN $38 \quad$ About $6 \mathrm{~cm}$ below the middle part of the left clavicle

RTN $39 \quad$ Corresponding to RTN 38 on the right side i.e. about $6 \mathrm{~cm}$ below middle part of the right clavicle

RTN $40 \quad$ Upper lateral part of the left breast (about $5 \mathrm{~cm}$ above and lateral to the left areola)

RTN 41 Medial to (to the right of) RTN 40 beside midline

RTN $42 \quad$ To the right of RTN 41

RTN $43 \quad$ Corresponding to RTN 40 on the right side (to the right of RTN 42).

RTN $44 \quad$ Just medial to the tip of the shoulder (on both sides).

RTN $45 \quad$ Posterior aspect of shoulder tip (on both sides).

RTN $46 \quad$ Below RTN 44 (below and medial to RTN 47 on both sides)

RTN $47 \quad$ Below and lateral to RTN 44 on both sides

RTN $48 \quad$ Below and lateral to RTN 50 (anteromedial to the left anterior superior iliac spine)

RTN 49 In the inguinal region (anteromedial to the right anterior superior iliac spine)

RTN 50 In the inguinal region (superior and medial to RTN48) (above external genitalia in pubic region)

RTN $51 \quad$ Superior and medial to RTN 49 (above external genitalia in pubic region)

RTN $52 \quad$ At ventral aspect of wrist region (overlying carpal tunnel on both sides)

N.B. This is a special anatomical area that should be taken with extreme care using Salah's technique.

RTN $53 \quad$ At dorsal aspect of wrist region (overlying carpal tunnel on both sides). N.B. This is a special anatomical area that should be taken with extreme care using Salah's technique.

Table 3e: Novel RTN (Rafeek tib nabawi, companion of prophetic medicine) anatomical sites for practicing Al-hijamah (Figures 1-4) 


\begin{tabular}{|l|l|}
\hline $\begin{array}{l}\text { Preventive aspects using } \\
\text { Al-hijamah }\end{array}$ & $\begin{array}{l}\text { Anatomical sites to which sucking cups } \\
\text { (cups of Al-hijamah) can be applied }\end{array}$ \\
\hline & $1-55$ \\
\hline & $2,3,11,32,36,43,44$ \\
$\cdot$ & RTN16, RTN 1, RTN2 \\
\hline
\end{tabular}

Table 4a: Al-hijamah as a prophylactic measure.

\begin{tabular}{|c|c|}
\hline $\begin{array}{l}\text { Diseases that can be } \\
\text { treated with Al-hijamah }\end{array}$ & $\begin{array}{l}\text { Anatomical sites to which sucking cups (cups of } \\
\text { Al-hijamah) can be applied }\end{array}$ \\
\hline $\begin{array}{l}\text { Fibromyalgia and } \\
\text { fibrositis }\end{array}$ & $\begin{array}{l}\text { Al-hijamah should be combined with conventional } \\
\text { treatment from a specialized physician. Al-hijamah may } \\
\text { better be practiced at: } \\
\quad 1-55 \\
\text { - } 49-120 \\
\text { - RTN1-RTN2 } \\
\text { Cups should be put at the painful sites (in the neck or } \\
\text { back region). } \\
\text { Cups should be put at the surrounding muscles. }\end{array}$ \\
\hline $\begin{array}{l}\text { Knee osteoarthritis } \\
\text { (Figure } 5 a \text { ) }\end{array}$ & $\begin{array}{l}\text { Al-hijamah should be combined with conventional } \\
\text { treatment from a specialized physician. Al-hijamah may } \\
\text { better be practiced at: } \\
\quad \text { - } 1-55 \\
\text { - } 9-10-11-12-13 \\
\text { - } 53 \text { (for right knee) or } 54 \text { (for left knee) } \\
\text { - RTN3-RTN4-RTN5-RTN6-RTN7-RTN8-RTN9 } \\
\text { N.B. Knee should be surrounded by putting 6-8 cups }\end{array}$ \\
\hline Back pain & $\begin{array}{l}\text { Al-hijamah should be combined with conventional } \\
\text { treatment from a specialized physician. Al-hijamah may } \\
\text { better be practiced at: } \\
\text { - } 1-55 \\
\text { Putting cup at sites of pain }\end{array}$ \\
\hline $\begin{array}{l}\text { Simple arthralgia, arthri- } \\
\text { tis and musculoskeletal } \\
\text { pain (Figure } 5 b \text { ) }\end{array}$ & $\begin{array}{l}\text { Al-hijamah should be combined with conventional } \\
\text { treatment from a specialized physician. Al-hijamah may } \\
\text { better be practiced at: } \\
\quad \text { - } 1-55 \\
\text { - RTN1-RTN2 } \\
\text { - } 9-10-11-12-13-49-120 \\
\text { N.B. Sucking cups should be put upon painful joints }\end{array}$ \\
\hline $\begin{array}{l}\text { Lumbar disc prolapse } \\
\text { (Figure } 5 \mathrm{c} \text { ) }\end{array}$ & $\begin{array}{l}\text { Al-hijamah should be combined with conventional } \\
\text { treatment from a specialized physician. Al-hijamah may } \\
\text { better be practiced at: } \\
\quad \text { 1-55 } \\
\text { - } 11-12-13-26-27-51-52-53-54 \\
\text { - RTN10-RTN11-RTN12-RTN13-RTN14-RTN15 } \\
\text { N.B. Putting cups on painful points in the back and lower } \\
\text { limbs is advisable }\end{array}$ \\
\hline Pain in general & $\begin{array}{l}\text { Al-hijamah should be combined with conventional } \\
\text { treatment from a specialized physician. Al-hijamah may } \\
\text { better be practiced at: } \\
\text { - Put cups on painful points } \\
\text { - Encircle painful points by cups }\end{array}$ \\
\hline $\begin{array}{l}\text { Neck pain, shoulder } \\
\text { pain and cervical disc } \\
\text { prolapse (Figure } 5 d \text { ) }\end{array}$ & $\begin{array}{l}\text { Al-hijamah should be combined with conventional } \\
\text { treatment from a specialized physician. Al-hijamah may } \\
\text { better be practiced at: } \\
\text { - } 1-55 \\
\text { - } 20-21-40-41-42 \\
\text { - RTN44-RTN45-RTN46-RTN47 } \\
\text { - Cups should be put at the painful sites (in the neck } \\
\text { or shoulder). } \\
\text { - Cups should be put at the surrounding muscles } \\
\text { (secondary source of pain) }\end{array}$ \\
\hline $\begin{array}{l}\text { Persistent non-specific } \\
\text { low back pain }\end{array}$ & $\begin{array}{l}\text { Al-hijamah should be combined with conventional } \\
\text { treatment from a specialized physician. Al-hijamah may } \\
\text { better be practiced at: } \\
\text { - } 1-55 \\
\text { - } 20-21-40-41-42 \\
\text { - RTN44-RTN45-RTN46-RTN47 } \\
\text { - Cups should be put at the painful sites (in the neck } \\
\text { or shoulder). } \\
\text { Cups should be put at the surrounding muscles } \\
\text { (secondary source of pain) }\end{array}$ \\
\hline
\end{tabular}

\begin{tabular}{|l|l|}
\hline $\begin{array}{l}\text { Persistent non-specific } \\
\text { low back pain }\end{array}$ & $\begin{array}{l}\text { Al-hijamah should be combined with conventional } \\
\text { treatment from a specialized physician. Al-hijamah may } \\
\text { better be practiced at: } \\
2-3-11-12-13\end{array}$ \\
& $\begin{array}{l}\text { RTN17-RTN18-RTN19-RTN20-RTN21 } \\
\text { Putting cups on painful points in the back and lower } \\
\text { limbs }\end{array}$ \\
\hline $\begin{array}{l}\text { Traumatic strain, sprain } \\
\text { and post-fracture } \\
\text { conditions }\end{array}$ & $\begin{array}{l}\text { Al-hijamah should be combined with conventional } \\
\text { treatment from a specialized physician. } \\
\text { Al-hijamah may better be practiced by putting sucking cups } \\
\text { over pain areas and surrounding it. }\end{array}$ \\
\hline $\begin{array}{l}\text { Plantar fasciitis } \\
\text { (Figure 5e) }\end{array}$ & $\begin{array}{l}\text { Al-hijamah should be combined with conventional } \\
\text { treatment from a specialized physician. Al-hijamah may } \\
\text { better be practiced at regions number: } \\
\text { - 1-55 } \\
\text { - RTN1-RTN2 } \\
\text {-9-10-11-12-13- 130 } \\
\text {-Apply cups to painful foot regions }\end{array}$ \\
\hline
\end{tabular}

Table 4b: Musculoskeletal pain conditions.

clearance from CPS. However, Al-hijamah sessions and number of cups can be divided into two or more sessions in light of patient's tolerability and practitioner's schedule. Each case should be individualized. First session should start with local regions directly overlying pathology sites, kahel region and akhdayin. In next sessions (may be the next day or within few days), remaining anatomical points should be done (better to be done with kahel, akhdayin for the second time if possible).

\section{Kahel Region and Akhdayin Regions}

Kahel region and akhdayin regions are the most important anatomical regions reported in prophetic medicine for practicing Al-hijamah. The exact anatomical definition for those sites is still controversial. Regarding kahel region, skin overlying seventh cervical vertebra is the anatomical point known by majority of practitioners (region \# 1). However region \#55 should be added to region \#1 when referring to kahel region. Some practitioners may like to add the interscapular region to both \#1 and \#55 when defining kahel region for performing Al-hijamah. For us, kahel region is a general anatomical site for practicing Al-hijamah for both preventive and therapeutic purposes and will benefit from including regions \#55 and interscapular regions i.e. complete kahel region includes $\# 1,55$, surrounding area and interscapular region. As for Akhdayin regions, they are 2 corresponding points. Literally, the word akhdayin in Arabic means the 2 jugular veins that run anatomically on both sides of the neck. Practically, Akhdayin regions are also controversial. Akhdayin regions are regions \#43 and 44 (nearest anatomical sites to jugular veins) although some people may refer to regions \#2 and 3 (behind both ears and at a distance from jugular veins) as akhdayin. Literally, regions \#43 and 44 are closer to the Arabic definition of akhdayin (i.e. more closer to jugular veins). We also confirm that regions \#43 and 44 are the akhdayin regions while regions $\# 2$ and 3 are the para-akhdayin regions (near akhdayin regions). This may help closer position to venous outflow of the brain (jugular veins). Concentration of calcitonin gene-related peptide, vasoactive intestinal polypeptide and other chemical mediators of headache are usually increased in jugular venous blood during attacks of cluster headache and migraine [1]. Future research is recommended to investigate if therapeutic outcomes of Al-hijamah at regions \#43 and 44 may be superior to regions \#2 and 3 in improving headache or enhancing blood clearance of the above-mentioned headache-related CPS. However, as regions \#43 and 44 are near anatomically to jugular veins, extreme care should be taken when doing Al-hijamah at those sites (special anatomical sites) where Salah's technique should be applied. Alhijamah at regions \#43 and 44 is very important according to prophetic 


\begin{tabular}{|c|c|}
\hline $\begin{array}{l}\text { Diseases that can be } \\
\text { treated with Al-hijamah }\end{array}$ & Anatomical sites to which sucking cups (cups of Al-hijamah) can be applied \\
\hline Hypertension (Figure 6a) & $\begin{array}{l}\text { Al-hijamah should be combined with conventional treatment from a specialized physician. Al-hijamah may better be practiced at } \\
\quad \text { - } 1-55 \\
\quad \text { RTN1-RTN2- RTN16 } \\
\text { - 2-3- 6-7-8-9-10-11-12-13-32-36-43-44-48-101 }\end{array}$ \\
\hline $\begin{array}{l}\text { Myocardial ischemia and } \\
\text { arrhythmia (Figure } 6 b \text { ) }\end{array}$ & $\begin{array}{l}\text { Al-hijamah should be combined with conventional treatment from a specialized physician. Al-hijamah may better be practiced at: } \\
\text { - } 1-55 \\
\text { - RTN1-RTN2 } \\
\text { - } 6-7-8-11-19-43-44-46-47-119-133-134\end{array}$ \\
\hline $\begin{array}{l}\text { Atherosclerosis } \\
\text { (Figure 6c) }\end{array}$ & $\begin{array}{l}\text { Al-hijamah should be combined with conventional treatment from a specialized physician. Regular pharmacological treatment should be } \\
\text { given. } \\
\text { Al-hijamah may better be practiced at: } \\
\text { - } 1-55-11 \\
\text { - RTN1-RTN2 } \\
\text { - Patient may benefit from applying cups locally at sites of atherosclerotic lesions. } \\
\text { - Patient may benefit from drinking a spoon of vinegar (Apple's vinegar before breakfast and dinner) }\end{array}$ \\
\hline $\begin{array}{l}\text { Hypotension } \\
\text { (Figure 6d) }\end{array}$ & $\begin{array}{l}\text { Al-hijamah should be combined with conventional treatment from a specialized physician. Al-hijamah may better be practiced at: } \\
\text { - } 1-55 \\
\text { - RTN1-RTN2 } \\
\text {-2-3-40-41-42-43-44 }\end{array}$ \\
\hline $\begin{array}{l}\text { Some conditions of circula- } \\
\text { tory insufficiency }\end{array}$ & $\begin{array}{l}\text { Al-hijamah should be combined with conventional treatment from a specialized physician. Al-hijamah may better be practiced at: } \\
\text { - } 1-55 \\
\text { - } 43-44 \\
\text { - RTN1-RTN2 } \\
\text { - Local areas of circulatory insufficiency }\end{array}$ \\
\hline $\begin{array}{l}\text { Ischemia of the leg } \\
\text { (Vascular thrombosis) }\end{array}$ & $\begin{array}{l}\text { Al-hijamah should be combined with conventional treatment from a specialized physician. Al-hijamah may better be practiced at: } \\
\text { - } 1-55 \\
\text { - } 11-12-13 \\
\text { - RTN1-RTN2 } \\
\text { - Cups should be put at the site of vascular thrombosis. } \\
\text { - Site of thrombosis should be surrounded by cups. }\end{array}$ \\
\hline
\end{tabular}

Table 4c: Cardiovascular diseases.

medicine. However, Al-hijamah at regions \#43 and 44 should never be done by a beginner or an unqualified practitioner as it is near jugular veins. Salah's technique may be needed to ensure a safe practice. On the contrary, Al-hijamah at regions number 2 and 3 is more safe and away from jugular veins. Research is needed to confirm therapeutic benefits of Al-hijamah at those different anatomical sites.

\section{Al-hijamah for Cerebrovascular Stroke and Diabetic Patients}

Practically, Al-hijamah is so beneficial for those patients although the benefit may not be felt in the short term. To cure diabetes mellitus (DM), a healthy pancreas with intact beta cells of islets of Langerhans for endogenous production of insulin is the curative treatment but this is still beyond possibility. Until this goal is achieved, DM is better treated by exogenous recombinant human insulin injection (for type I DM) or oral hypoglycemics (for type II DM) [79]. As for stroke patients, permanent neuron death occurs due to either cerebral hemorrhage or infraction. Treatment for stroke patients is directed towards preserving normal structure and function of remaining healthy neurons and to prevent or relieve neurological sequelae of stroke. Combining $\mathrm{Al}$ hijamah with diet control, hypoglycemic treatment and costus for DM is expected to benefit patients so much. Combining Al-hijamah with physiotherapy and regular treatment for stroke patients may prevent progression towards irreversible sequelae. Both DM and stroke patients can benefit too much -from Al-hijamah- in delaying or preventing the development of serious complications. Diabetic and stroke patients may not feel an immediate improvement after practicing Al-hijamah as no dramatic relief of clinical picture occurs. However, Al-hijamah effectively corrects predisposing factors for progression of disease complications as Al-hijamah will treat hyperlipidemia [80], hypertension [80] and myocardial ischemia [81]. Al-hijamah clears blood of diabetic patients through excreting DRS e.g. advanced glycation end products (AGEPs), which may worsen the prognosis of DM. Al-hijamah treats diabetic foot (Table 1), while local honey application to diabetic wounds improves healing of diabetic wounds and ulcers [82-85]. Both Al-hijamah and honey are remedies of prophetic medicine $[2,5,14]$. At sites of limb paralysis in stroke patients, Al-hijamah improves local circulation [1], which may benefit the therapeutic role of physiotherapy.

\section{Anatomical Sites for Al-hijamah in Diabetic Foot and Misconceptions Related to it}

Regarding diabetic foot, treatment using conventional adjustment of blood glucose level, care of diabetic wounds and regular intake of broad spectrum antibiotics is a must [86]. However, understanding pathogenesis of diabetic foot helps to improve therapeutic lines and hence therapeutic outcome. Certain steps in the pathogenesis of diabetic foot may facilitate the development of diabetic foot ulcers and infection: hyperglycemic interstitial fluid in diabetic foot (suitable for bacterial growth and multiplication), AGEPs, poor local circulation and neuropathy are critical for progression to ischemia and gangrene [8791]. Al-hijamah may be the sole treatment to treat such pathogenesis criteria. Al-hijamah may drain CPS related to pathogenesis of diabetic foot through non-specific clearance of interstitial fluids and circulation from both DCS and DRS [1,2]. Al-hijamah may treat diabetic foot ulcers and infection, drain hyperglycemic interstitial fluid, excrete AGEPs, improve local capillary and blood circulation and enhance natural immunity. Practicing Al-hijamah for treating diabetic foot should be done after evaluation of the foot by an experienced vascular surgeon. Alhijamah can be done at anatomical sites in the back of the trunk, head and neck (kahel region and akhdayin regions) i.e. away from diabetic foot region to clear blood from accumulating metabolic diabetic CPS (including AGEPs) and enhance endogenous production of nitric oxide (vasodilator) [1] to correct limb ischemia. No need to practice 
Citation: Mahmoud HS, Abou-El-Naga M, Omar NAA, El-Ghazzawy HA, Fathy YM, et al. (2013) Anatomical Sites for Practicing Wet Cupping Therapy (Al-Hijamah): In Light of Modern Medicine and Prophetic Medicine. Altern Integ Med 2: 138. doi:10.4172/2327-5162.1000138

Page 12 of 30

\begin{tabular}{|c|c|}
\hline $\begin{array}{l}\text { Diseases that can be treated with } \\
\text { Al-hijamah }\end{array}$ & Anatomical sites to which sucking cups (cups of Al-hijamah) can be applied \\
\hline $\begin{array}{l}\text { Headache and Migraine } \\
\text { (Figure } 7 a)\end{array}$ & $\begin{array}{l}\text { Al-hijamah should be combined with conventional treatment from a specialized physician. Treatment of the cause of } \\
\text { headache is the most important. Al-hijamah may better be practiced at: } \\
\text { - } 1-55 \\
\text { - 2-3-32-34-35-36-39-41-42-43-44-101-104-105 } \\
\text { • RTN16 } \\
\text { - Put sucking cups over head areas having headache } \\
\text { N.B. Regions of pain in the head are the most important for doing Al-hijamah (taking care from the anatomy of head } \\
\text { regarding the course of superficial arteries, veins and nerves). It is better to use very superficial skin scarification. At sites of } \\
\text { superficial structures, it is recommended to be done by an expert where Salah's technique is advisable. }\end{array}$ \\
\hline $\begin{array}{l}\text { Carpal tunnel syndrome } \\
\text { (Figure } 7 b \text { ) }\end{array}$ & $\begin{array}{l}\text { Al-hijamah should be combined with conventional treatment from a specialized physician. Al-hijamah may better be } \\
\text { practiced at: } \\
\text { - 1-55 } \\
\text { - RTN52-RTN53 } \\
\text { - } 20-21-40-41-42 \\
\text { - The area overlying the trapezius muscle if there are adhesions, pain or poor microcirculation by inspection) } \\
\text { - Cups should be put at the painful sites (in the neck or wrist region). } \\
\text { N.B. Skin overlying carpal tunnel is a highly dangerous area due to presence of superficial veins, both radial artery (most } \\
\text { laterally), ulnar artery (most medially) and superficial veins. It should not be done by an ordinary practitioner but it is highly } \\
\text { recommended to be done in hospitals by an expert using Salah's technique. }\end{array}$ \\
\hline $\begin{array}{l}\text { Epilepsy (Figure 7c) } \\
\text { N.B. Results of treating Epilepsy using Al- } \\
\text { hijamah are better in adults than children }\end{array}$ & 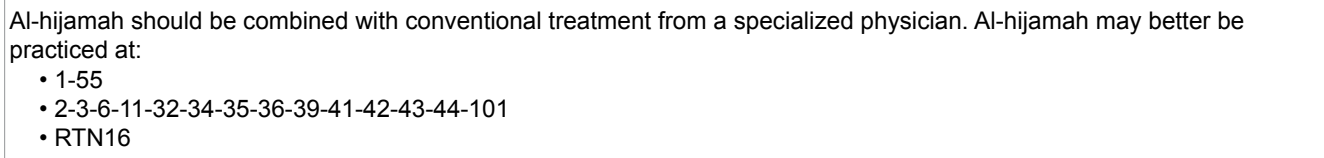 \\
\hline $\begin{array}{l}\text { Early cerebral infarction } \\
\text { (Figure } 7 d \text { ) }\end{array}$ & $\begin{array}{l}\text { Al-hijamah should be combined with conventional treatment from a specialized physician. Al-hijamah may better be } \\
\text { practiced at: } \\
\text { - } 1-55 \\
\text { - } 2-3-6-7-8-9-10-11-12-13-32-33-34-35-36-41-42-43-44-101 \\
\text { - RTN1-RTN2-RTN16 } \\
\text { - When speech is affected, add also regions number:106-114 }\end{array}$ \\
\hline Brachialgia paraesthetica nocturna & $\begin{array}{l}\text { Al-hijamah should be combined with conventional treatment from a specialized physician. Al-hijamah may better be } \\
\text { practiced at: } \\
\text { - } 1-55 \\
\text { - } 20-21-40-41-42 \\
\text { - The area overlying the trapezius muscle if there are adhesions, pain or poor microcirculation by inspection) } \\
\text { - Cups should be put at the painful sites (in the neck or wrist region). }\end{array}$ \\
\hline $\begin{array}{l}\text { Trigeminal neuralgia, trigeminal neuritis and } \\
\text { facial neuritis (Figure } 7 \mathrm{e} \text { ) }\end{array}$ & $\begin{array}{l}\text { Al-hijamah should be combined with conventional treatment from a specialized physician. Al-hijamah may better be } \\
\text { practiced at: } \\
\quad \text { - } 1-55 \\
\text { - } 2-3-32-36-43-44-49 \\
\text { - } 110-111-112-113-114-120 \\
\text { - RTN16. } \\
\text { - On affected region }\end{array}$ \\
\hline $\begin{array}{l}\text { Laziness, lassitude and somnolence } \\
\text { (Figure 7f) }\end{array}$ & $\begin{array}{l}\text { Al-hijamah should be combined with conventional treatment from a specialized physician. Al-hijamah may better be } \\
\text { practiced at: } \\
\quad \text { 1-55 } \\
\text { - RTN1-RTN2 -RTN16 } \\
\text { 2-3-6-11-32-34-35- 36- 43-44 }\end{array}$ \\
\hline $\begin{array}{l}\text { To improve memory and concentration } \\
\text { (Figure } 7 \mathrm{~g} \text { ) }\end{array}$ & $\begin{array}{l}\text { Al-hijamah should be combined with conventional treatment from a specialized physician. Al-hijamah may better be } \\
\text { practiced at: } \\
\quad \text { 1-55 } \\
\text {-2-3-41-42-32-34-35-36-39- 43- 44-101 } \\
\text { - RTN1- RTN2-RTN16 }\end{array}$ \\
\hline $\begin{array}{l}\text { Some psychiatric conditions } \\
\text { (Figure } 7 \mathrm{~h} \text { ) }\end{array}$ & $\begin{array}{l}\text { Al-hijamah should be combined with conventional treatment from a specialized physician. Al-hijamah may better be } \\
\text { practiced at: } \\
\quad \text { 1-55 } \\
\text { - RTN1-RTN2 -RTN16 } \\
\cdot \text { - } 2-3-6-11-32-34-35-36-39-41-42-43-44-101\end{array}$ \\
\hline
\end{tabular}

Table 4d: Neuropsychiatric diseases.

Al-hijamah at diabetic foot itself or lower limb region as long as there is no gangrene or impending gangrene. If there's gangrene, excision gangrenous tissue is a must of. When there is impending gangrene or gangrene, Al-hijamah is advisable at both general anatomical sites (in the back region and back of neck) and at limb region (to drain local pathogenic interstitial fluid with CPS and enhance local endogenous production of nitric oxide to improve local blood circulation) through covering medial and lateral aspects of leg (below knee) and dorsal aspect of diabetic foot with cups and taking extreme care of skin scarifications (should be superficial to the depth of $0.1 \mathrm{~mm}$ ) and taking care not to injure superficial veins (avoid their course).

However, skin scarifications $(0.1 \mathrm{~mm}$ in depth and $1-2 \mathrm{~mm}$ in length) done during Al-hijamah may seem strange and not welcomed when discussing Al-hijamah for treating diabetic foot as a preventive 
Citation: Mahmoud HS, Abou-El-Naga M, Omar NAA, El-Ghazzawy HA, Fathy YM, et al. (2013) Anatomical Sites for Practicing Wet Cupping Therapy (Al-Hijamah): In Light of Modern Medicine and Prophetic Medicine. Altern Integ Med 2: 138. doi:10.4172/2327-5162.1000138

Page 13 of 30

\begin{tabular}{|c|c|}
\hline Diseases that can be treated with Al-hijamah & Anatomical sites to which sucking cups (cups of Al-hijamah) can be applied \\
\hline Gastritis (Figure 8a) & $\begin{array}{l}\text { Al-hijamah should be combined with conventional treatment from a specialized physician. Al-hijamah may better be } \\
\text { practiced at: } \\
\quad \text { - } 1-55 \\
\cdot 7-8-49-43-44-50-120-121\end{array}$ \\
\hline $\begin{array}{l}\text { Irritable bowel syndrome } \\
\text { (Figure } 8 b \text { ) }\end{array}$ & $\begin{array}{l}\text { Al-hijamah should be combined with conventional treatment from a specialized physician. Al-hijamah may better be } \\
\text { practiced at: } \\
\text { - 1-55 } \\
\text { - RTN1- RTN2- RTN17-RTN18-RTN19-RTN20- RTN21 } \\
\text {-6-7-8-48-14-15-16-17-18-45-46-121 }\end{array}$ \\
\hline
\end{tabular}

Table 4e: Gastrointestinal diseases.

\begin{tabular}{|c|c|}
\hline Diseases that can be treated with Al-hijamah & Anatomical sites to which sucking cups (cups of Al-hijamah) can be applied \\
\hline $\begin{array}{l}\text { Bronchial asthma (Figure 9a) } \\
\text { N.B. Results of treating bronchial asthma using } \\
\text { Al-hijamah are better in children than adults }\end{array}$ & $\begin{array}{l}\text { Al-hijamah should be combined with conventional treatment from a specialized physician. Al-hijamah may better be } \\
\text { practiced at: } \\
\text { - } 1-55 \\
\text { - TN1-RTN2-RTN38-RTN39-RTN40-RTN41-RTN42-RTN43 } \\
\text { - 4-5-9-10-49 } \\
\text { - } 115-116-117-118-120-135-136 \\
\text { - When there is an associated sinusitis, al-hijamah can be done at more than one session to include all the anatomi- } \\
\text { cal sites. }\end{array}$ \\
\hline Motion sickness (Figure 9b) & $\begin{array}{l}\text { Al-hijamah should be combined with conventional treatment from a specialized physician. Al-hijamah may better be } \\
\text { practiced at: } \\
\quad \text { 1-55 } \\
\text { • RTN1-RTN2- RTN16 } \\
\text { • } 2-3-20-21-41-42-32-36 \\
\text { Anatomical sites to which sucking cups (cups of Al-hijamah) can be applied }\end{array}$ \\
\hline Tonsillitis (Figure 9c) & $\begin{array}{l}\text { Al-hijamah should be combined with conventional treatment from a specialized physician. Al-hijamah may better be } \\
\text { practiced at: } \\
\text { - } 1-55 \\
\text { - } 20-21-41-42-43-44-49-114-120 \\
\text { - RTN1-RTN2 }\end{array}$ \\
\hline Chronic sinusitis (Figure 9d) & $\begin{array}{l}\text { Al-hijamah should be combined with conventional treatment from a specialized physician. Al-hijamah may better be } \\
\text { practiced at: } \\
\quad \text { 1-55 } \\
\text { • RTN1- RTN2 } \\
\text { - 32-36-49-120-102-103-108-109-114 } \\
\text { N.B. Al-hijamah may be helpful and MUST BE done very carefully using Salah's technique for points in dangerous area } \\
\text { of the face. }\end{array}$ \\
\hline Otitis media (Figure 9e) & $\begin{array}{l}\text { Al-hijamah should be combined with conventional treatment from a specialized physician. Al-hijamah may better be } \\
\text { practiced at: } \\
\begin{array}{l}\text { - } 1-55 \\
\text { - RTN1- RTN2- RTN27 - RTN28 } \\
\text { - } 2-3-20-21-37-38-41-42-49-120\end{array}\end{array}$ \\
\hline
\end{tabular}

Table 4f: Respiratory and ENT diseases.

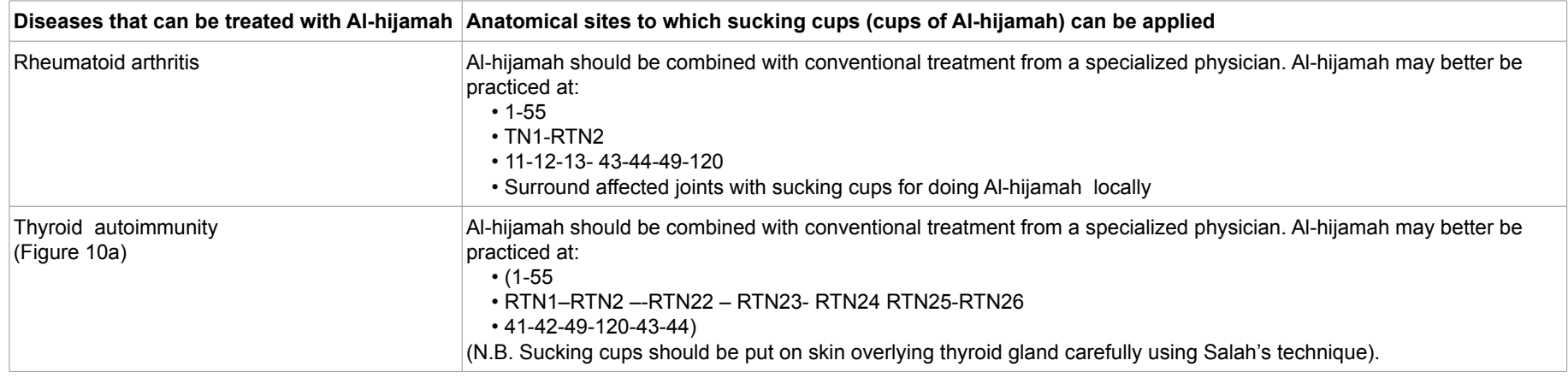

Table 4g: Autoimmune diseases.

measure and as an adjuvant therapeutic line of treatment. Poor healing power in diabetic foot wounds may be the cause why some physicians may not recommend doing Al-hijamah for treating diabetic foot. On the contrary, Al-hijamah creates so superficial skin scratches that can never be described as wounds i.e. non-full thickness skin wounds. Skin scarifications during Al-hijamah and suction pressure will increase endogenous production of nitric oxide (vasodilator and antimicrobial) and enhance capillary vascular blood flow, lymphatic and capillary microcirculation. Skin scarifications for diabetic foot are so shallow, short, sterile, associated with production of nitric oxide (vasodilator, antimicrobial and promote wound healing), followed by suction of stagnant unhealthy hyperglycemic local interstitial fluids and is associated with other health benefits of Al-hijamah e.g. enhancing natural immunity [1]. Accidental wounds in diabetic foot differ in all previously-mentioned criteria. 
Citation: Mahmoud HS, Abou-El-Naga M, Omar NAA, El-Ghazzawy HA, Fathy YM, et al. (2013) Anatomical Sites for Practicing Wet Cupping Therapy (Al-Hijamah): In Light of Modern Medicine and Prophetic Medicine. Altern Integ Med 2: 138. doi:10.4172/2327-5162.1000138

Page 14 of 30

\begin{tabular}{|c|c|}
\hline Diseases that can be treated with Al-hijamah & Anatomical sites to which sucking cups (cups of Al-hijamah) can be applied \\
\hline $\begin{array}{l}\text { Gout and gouty arthritis } \\
\text { (Figure 10b) }\end{array}$ & $\begin{array}{l}\text { Al-hijamah should be combined with conventional treatment from a specialized physician. Al-hijamah may better be } \\
\text { practiced at anatomical points number: } \\
\text { - } 1-55 \\
\text { - RTN1-RTN2 } \\
\text { - } 9-10-11-12-13-28-29-30-31-121 \\
\text { - Put cups at points of pain in legs and feet and where urate crystals are deposited. }\end{array}$ \\
\hline $\begin{array}{l}\text { Thyroid dysfunction } \\
\text { (Figure 10a) }\end{array}$ & $\begin{array}{l}\text { Al-hijamah should be combined with conventional treatment from a specialized physician. Al-hijamah may better be } \\
\text { practiced at: } \\
\quad \text { - 1-55 } \\
\text { - RTN1-RTN2 --RTN22 - RTN23- RTN24 RTN25-RTN26 } \\
\text { - 41-42-43-44-49-120 } \\
\text { (N.B. Sucking cups should be put on skin overlying thyroid gland carefully using Salah's technique). }\end{array}$ \\
\hline $\begin{array}{l}\text { Conditions of hormonal imbalance } \\
\text { (Figure 10c) }\end{array}$ & $\begin{array}{l}\text { Al-hijamah should be combined with conventional treatment from a specialized physician. Al-hijamah may better be } \\
\text { practiced at: } \\
\quad \text { - } 1-55 \\
\quad \text { 2-3-6-32-34-35-36-39-41-42-49-101-120 } \\
\text { - RTN1-RTN2-RTN16 }\end{array}$ \\
\hline $\begin{array}{l}\text { Hyperlipidemia and hypercholesterolemia } \\
\text { (Figure 10d) }\end{array}$ & $\begin{array}{l}\text { Al-hijamah should be combined with conventional treatment from a specialized physician. Al-hijamah may better be } \\
\text { practiced at: } \\
\quad \text { 1-55 } \\
\text { - RTN1-RTN2-RTN30-RTN31-RTN32-RTN33-RTN34-RTN35 } \\
\text { - 6-7-8-11-41-42-48 }\end{array}$ \\
\hline
\end{tabular}

Table 4h: Metabolic conditions.

\begin{tabular}{|c|c|}
\hline Diseases that can be treated with Al-hijamah & Anatomical sites to which sucking cups (cups of Al-hijamah) can be applied \\
\hline Cellulitis & $\begin{array}{l}\text { Al-hijamah should be combined with conventional treatment from a specialized physician. Al-hijamah may better be } \\
\text { practiced at: } \\
\text { - } 1-55 \\
\text { - } 43-44-49-120 \\
\text { - RTN1-RTN2 } \\
\text { - Directly put as many cups as you can at cellulitis region to include it all and also at points of poor microcirculation } \\
\text { near cellulitis region }\end{array}$ \\
\hline Some viral infections e.g. herpes zoster & $\begin{array}{l}\text { Al-hijamah should be combined with conventional treatment from a specialized physician. Al-hijamah may better be } \\
\text { practiced at: } \\
\text { - } 1-55 \\
\text { - } 2-3-49-120 \\
\text { - RTN1-RTN2 } \\
\text { - Apply cups to skin overlying or as near as possible to affected areas }\end{array}$ \\
\hline $\begin{array}{l}\text { Viral hepatitis } B \text { and } C \\
\text { (Figure 11a) }\end{array}$ & $\begin{array}{l}\text { Al-hijamah should be combined with conventional treatment from a specialized physician. Al-hijamah may better be } \\
\text { practiced at: } \\
\text { - } 1-55 \\
\text { - RTN1- RTN2- RTN30-RTN31-RTN32 -RTN33 - RTN34- RTN35- RTN36- RTN37 } \\
\text { - 6-7-8-9-10-11-41-42--49-120-121 } \\
\text { - About } 5 \text { cups may better be put on right thigh and dorsum of right foot. }\end{array}$ \\
\hline $\begin{array}{l}\text { Diabetic foot } \\
\text { (Figure 11b) }\end{array}$ & $\begin{array}{l}\text { Al-hijamah should be combined with conventional treatment from a specialized physician. Al-hijamah may better be } \\
\text { practiced at: } \\
\text { - } 1-55 \\
\text { - } 6-7-8-11-12-13-22-23-24-25-43-44-49-120 \\
\text { - } 125-126 \\
\text { - RTN1 - RTN2-RTN29 } \\
\text { N.B. } \\
\text { - Each case should be evaluated and individualized. } \\
\text { - RTN } 29 \text { is the most important for clearance of interstitial fluids, put as many cups as you can). }\end{array}$ \\
\hline
\end{tabular}

Table 4i: Infections.

\section{Some Diseases in which Patients may apparently Benefit to a Small Extent with Al-hijamah}

As a golden rule, Al-hijamah will benefit every patient as we will discuss below and there is no reported harm carried by proper practice of Al-hjjamah. The degree of health benefits after Al-hijamah ranges from cure to improvement according to disease condition when Alhijamah is used as a sole treatment. Combining current medical and surgical treatments with Al-hijamah expands its spectrum and effectiveness.

Taking into account the excretory benefit, immunological benefit, metabolic benefit and other therapeutic benefits of Al-hijamah [1], we may get the sense when and for how many times we should perform Alhijamah and to what extent we can expect the improvement.

Al-hijamah practitioners may report that Al-hijamah- as a sole treatment- may not cure gastric ulcer, obesity, cataract, astigmatism, delayed speaking, azoospermia, anal fissure, piles, hernia, peripheral neuropathy, urinary incontinence, renal stones, gall stones, liver cirrhosis, peripheral nerve atrophy, lipoma, snoring, varicocele, polycystic ovary, cancer, insomnia, osteoporosis and others.

However, in patients with the above-mentioned diseases, it is 


\begin{tabular}{|c|c|}
\hline Diseases that can be treated with Al-hijamah & Anatomical sites to which sucking cups (cups of Al-hijamah) can be applied \\
\hline Conditions of impaired immunity (Figure 12a) & $\begin{array}{l}\text { Al-hijamah should be combined with conventional treatment from a specialized physician. Al-hijamah may better be } \\
\text { practiced at: } \\
\quad \text { - } 1-55 \\
\text { - RTN1-RTN2 } \\
\text { - } 43-44-49-120\end{array}$ \\
\hline $\begin{array}{l}\text { Glaucoma } \\
\text { (Figure 12b) }\end{array}$ & $\begin{array}{l}\text { Al-hijamah should be combined with conventional treatment from a specialized physician. Al-hijamah may better be } \\
\text { practiced at: } \\
\quad \text { - } 1-55 \\
\quad \text { 2-3-9-10-11-32-34-35-36-41-42-101-104-105 } \\
\cdot \text { RTN16 }\end{array}$ \\
\hline Pain of dysmenorrhea & $\begin{array}{l}\text { Al-hijamah should be combined with conventional treatment from a specialized physician. Al-hijamah may better be } \\
\text { practiced at: } \\
\text { - } 1 \text {-55 } \\
\text { • RTN1-RTN2-RTN48, RTN49, RTN50, RTN51 } \\
\text { - 11-12-13-125-126 } \\
\text { N.B. Performing dry cupping therapy below both breasts may be useful }\end{array}$ \\
\hline $\begin{array}{l}\text { Some ovulatory disorders (cause of female } \\
\text { infertility, which may be due hyperestrogenemia }\end{array}$ & $\begin{array}{l}\text { Al-hijamah should be combined with conventional treatment from a specialized physician. Al-hijamah may better be } \\
\text { practiced at: } \\
\quad \text { - } 1-55 \\
\text { - RTN1-RTN2-RTN48, RTN49, RTN50, RTN51 } \\
\cdot \text {-2-3-11-12-13-32-36-39-125-126 }\end{array}$ \\
\hline
\end{tabular}

Table 4j: Miscellaneous.

better not to do Al-hijamah as a sole treatment. Instead, it is better to combine current medical and surgical treatments with Al-hijamah to expand its spectrum and effectiveness. For example, obesity due to endocrine causes may benefit from Al-hijamah through clearing blood from excess causative hormones (CPS), while immunological and pharmacological potentiation exerted by Al-hijamah will benefit cancer patients. Al-hijamah is beneficial for preventive purposes even in healthy subjects as Al-hijamah induces non-specific clearance of blood and interstitial fluids from CPS through clearing blood of patients with diabetic neuropathy form AGEPs, normalizing blood chemistry and decreasing the damage in nerve cells due to diabetic metabolic disturbances. In addition, there is a long list of therapeutic health benefits of sAl-hijamah as previously reported in the evidence-based Taibah theory [1] e.g. general benefit (may include improvement of general condition), detoxification benefit, immunological benefit (via enhancing natural immunity, increasing number of natural killer cells and enhancing immunostimulatory cytokines [92,93], neurological benefit (improving headache), hemodynamic benefit (improving local capillary circulation), angiogenic benefit, hemostatic benefit, hematological benefit (blood clearance of CPS and old hemolyzed blood cells), cosmetic benefit (breaking adhesions, resolving inflammation and swelling), pharmacological benefit (potentiating and facilitating therapeutic effects of drugs simultaneously administered with $\mathrm{Al}$ hijamah through removing disease CPS), analgesic benefit (through stimulating the release of endogenous opioids and excreting painrelated substances), excretory benefit (of CPS and noxious substances), metabolic benefit (improving cellular perfusion), nutritional benefit (decreasing LDL and cholesterol), psychological benefit (secondary to all benefits and due to improvement of affective component of pain) and treatment of disease predisposing factors [1]. However, extent of therapeutic benefit may be greatly enhanced upon combining $\mathrm{Al}$ hijamah with other components of the pentad of cure as we will discuss here.

\section{Pentad of Cure of Prophetic Medicine (PCPM)}

Many remedies reported in prophetic medicine are so helpful in treating many disease conditions. Such remedies include pentad of cure of prophetic medicine (PCPM) e.g. nigella sativa [94-99], honey (oral and local administration) [100-105], costus [106,107] and Ajwat of Aliah [108]. Combination of such remedies with Al-hijamah is expected to expand therapeutic spectrum of Al-hijamah. In addition, therapeutic synergism is strongly expected when components of PCPM are combined together as a whole or partial combination.

\section{Conclusion and Recommendations}

Al-hijamah is an excretory procedure having both medical and scientific bases in clearing blood, lymphatics and interstitial spaces from CPS and noxious substances. Both modern medicine and prophetic medicine proved the beneficial value of Al-hijamah in treatment of different diseases with different pathogeneses. We really appreciate so much that the Chinese are pioneering in practicing cupping therapy officially in their hospitals in a pure medical atmosphere. We appreciate also that Al-hijamah is officially practiced in hospitals in United Arab Emirates. We recommend practicing Al-hijamah officially in all hospitals for treating human diseases for the great benefits of this promising line of treatment.

Miraculous remedies in prophetic medicine are a heritage (legacy) for the whole humanity. The prophet Muhammad peace be upon him is being described in the Holy Qur'an as a mercy for the whole humanity and a mercy for all people [109]. Researchers worldwide are invited to pay more attention to develop more research in investigating remedies and therapeutic treasures practiced in prophetic medicine to cure and relieve human suffering in many incurable diseases with dismal prognosis.

The majestic deep-rooted Egyptian Universities as Al-Azhar, Cairo, Alexandria Universities and the internationally ranked King Saud University, Taibah University, Islamic University in Al-Madinah and Om Al-Quraa University in Makkah in Saudi Arabia (homeland of prophethood and prophetic medicine) are invited to guide research and researchers to introduce remedies and treasures in prophetic medicine to scientific and medical humanity literature. The pioneering report of Sahbaa Ahmed (Al-Azhar University) in treating rheumatoid arthritis using Al-hijamah [93] is well cited and appreciated.

WHO is invited to shed more light upon health benefits of $\mathrm{Al}$ hijamah and to encourage its practice in hospitals in the western world. Ministries of health worldwide and in the Arab world are invited to allow and encourage the practice of Al-hijamah in hospitals officially in 
A

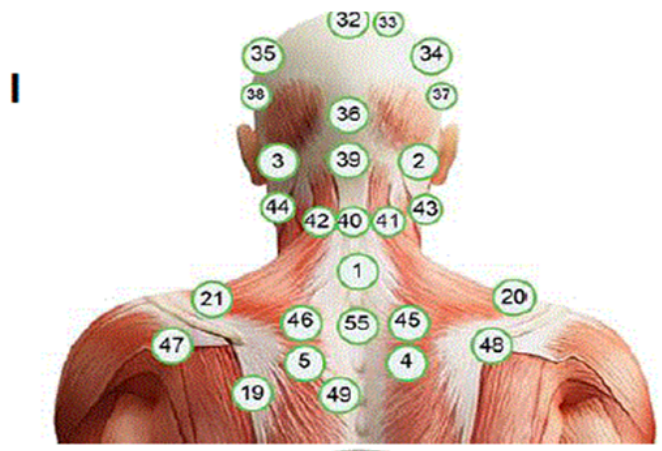

II

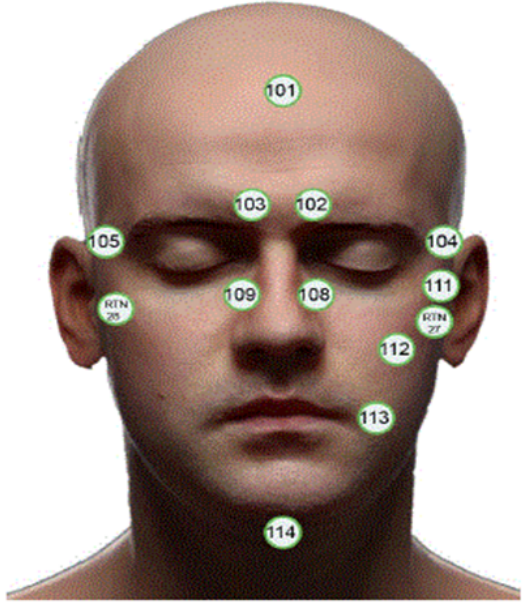

B

I<smiles></smiles>

(32)

(101)

(35)

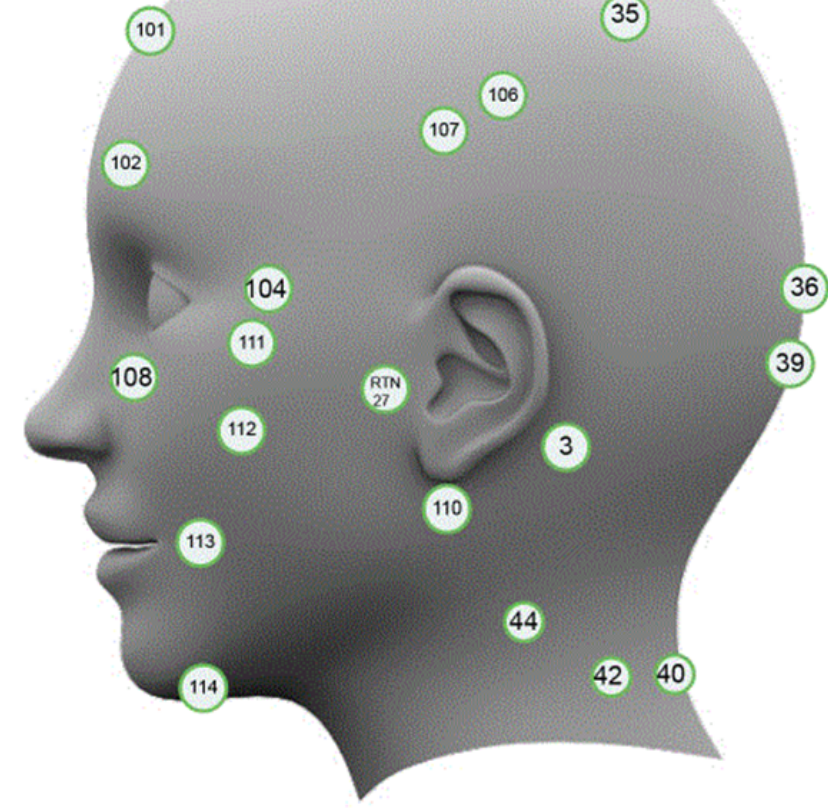

Figure 1: Anatomical sites for practicing Al-hijamah at head and neck regions. a. Back of head and neck [66], b. [67] and c [68]. Face region- d. Lateral aspect of skull [69]. 
A
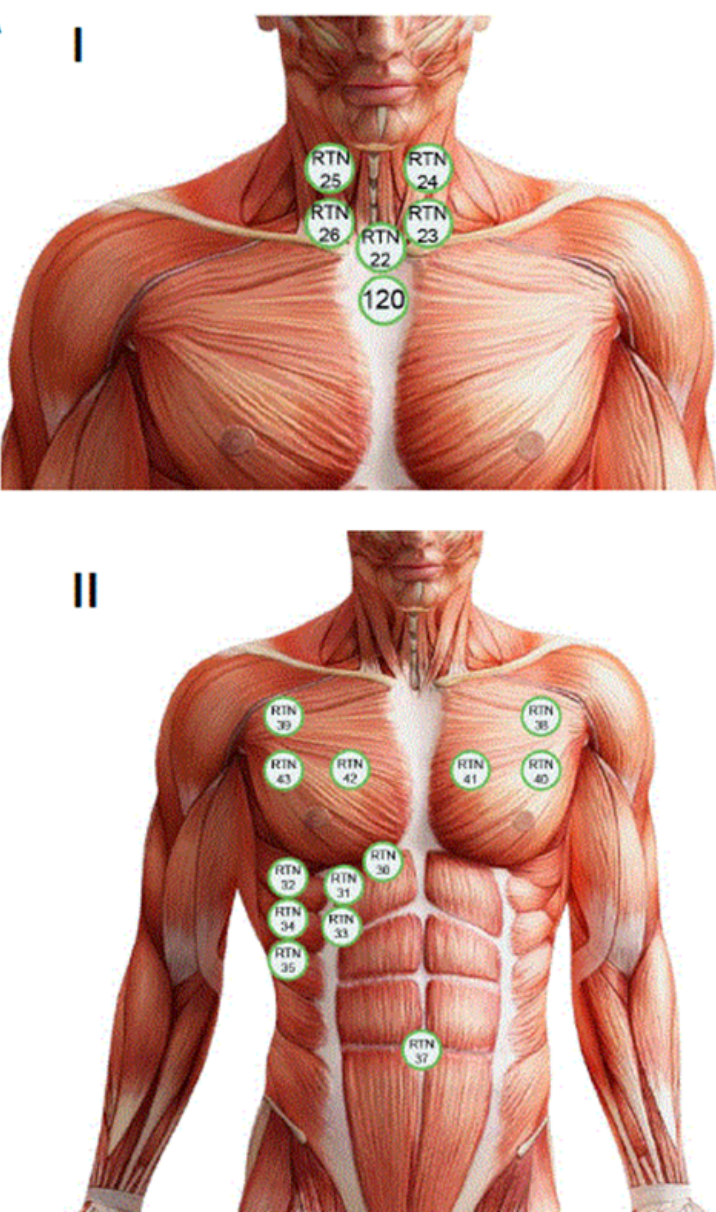

B

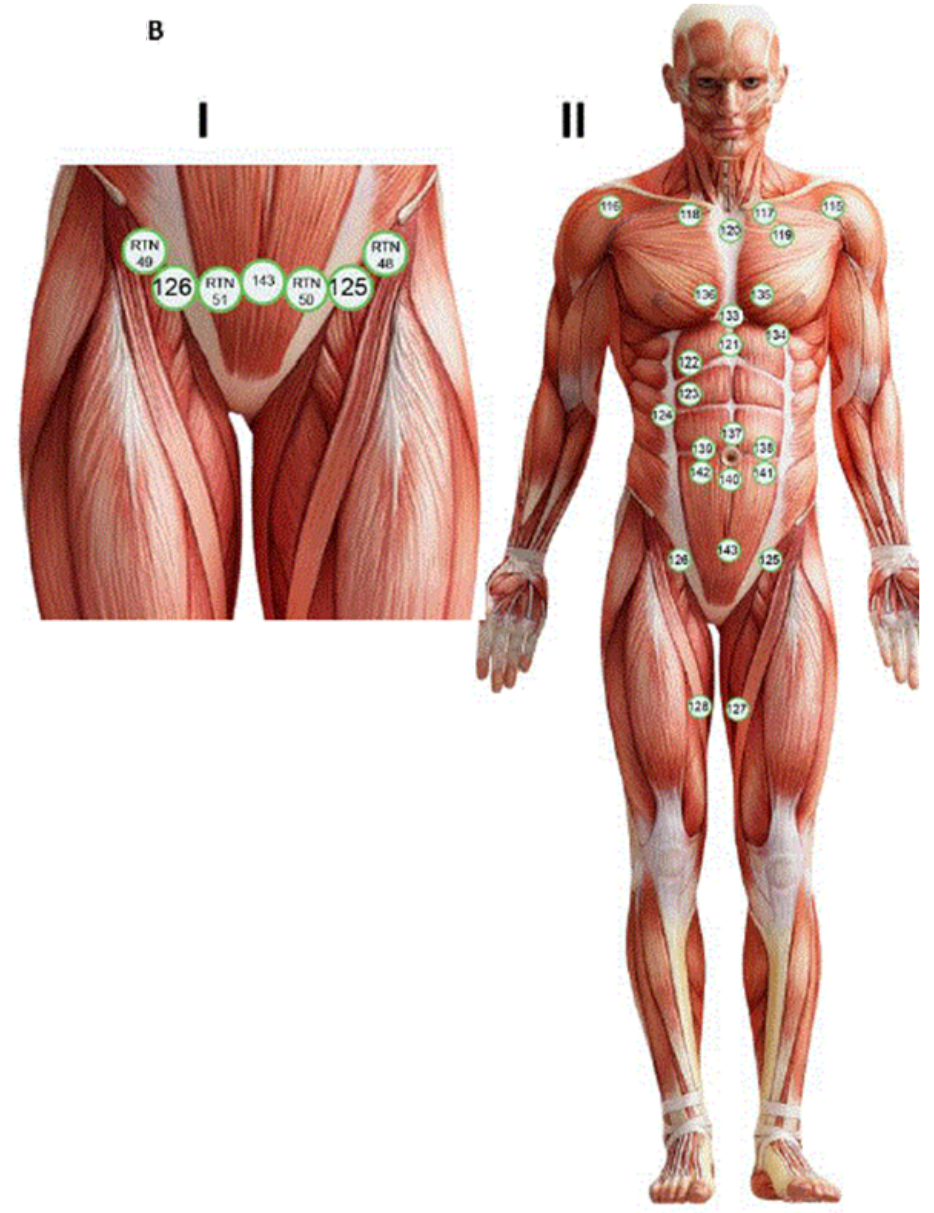

Figure 2: Anatomical sites for practicing Al-hijamah at frontal aspect of chest, abdomen and pelvis regions. a-b [70] and c [67]. 


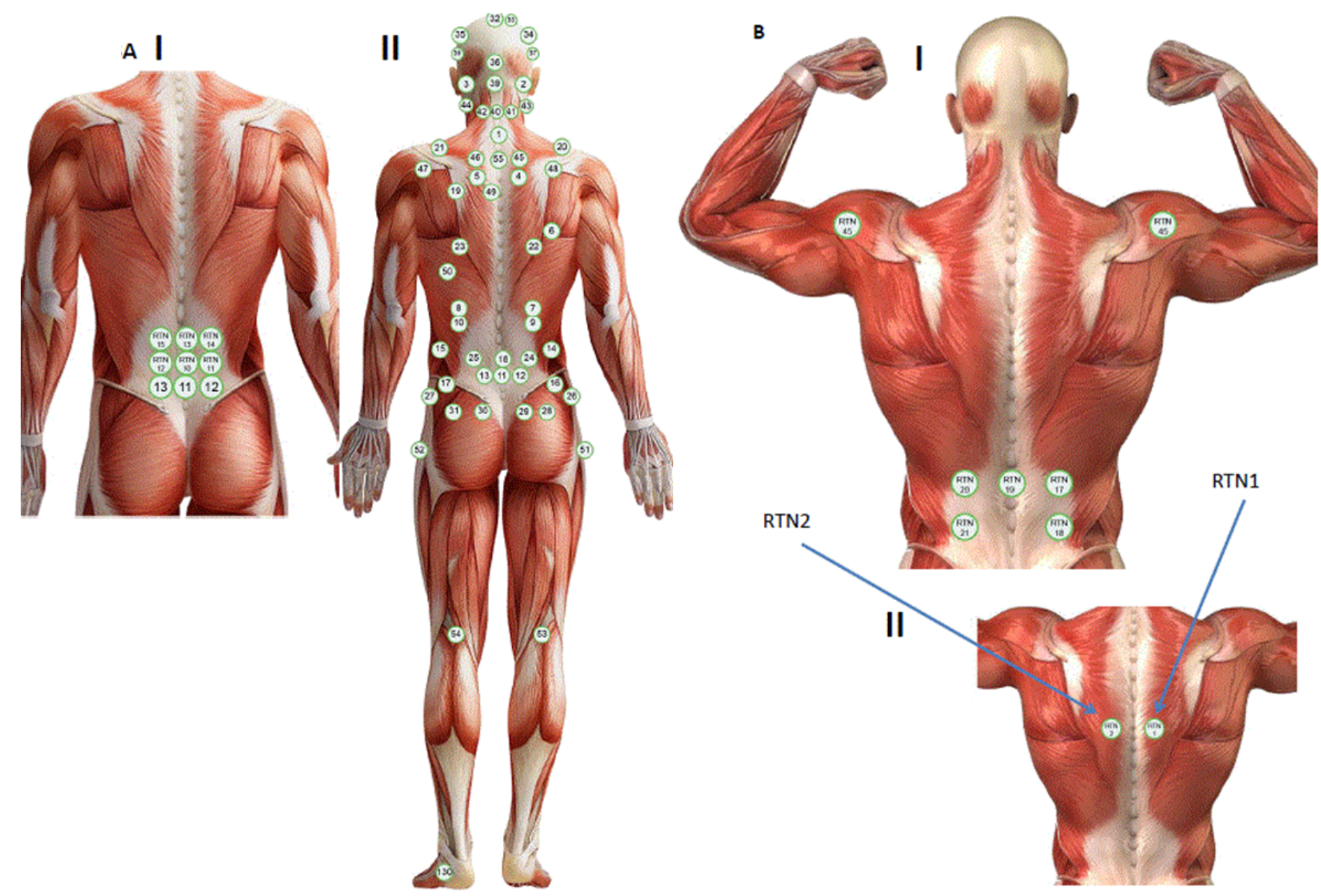

Figure 3: Anatomical sites for practicing Al-hijamah at back region (back of trunk) and at back of lower limbs. a-b [66], c [71] and d [66]. 
A

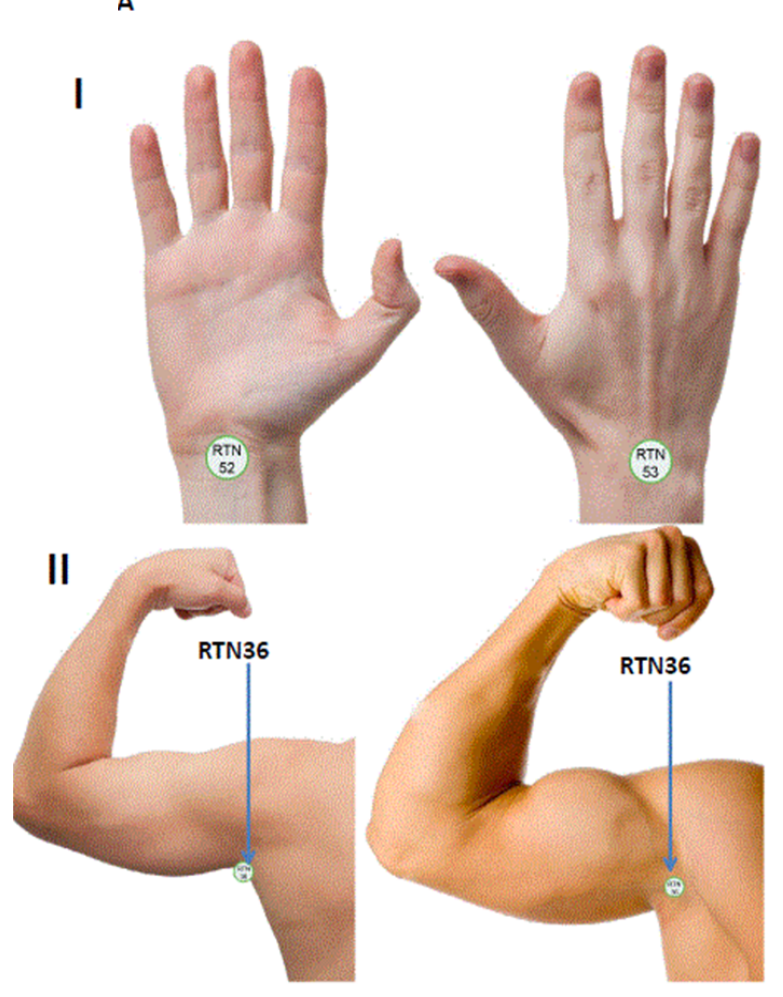

II

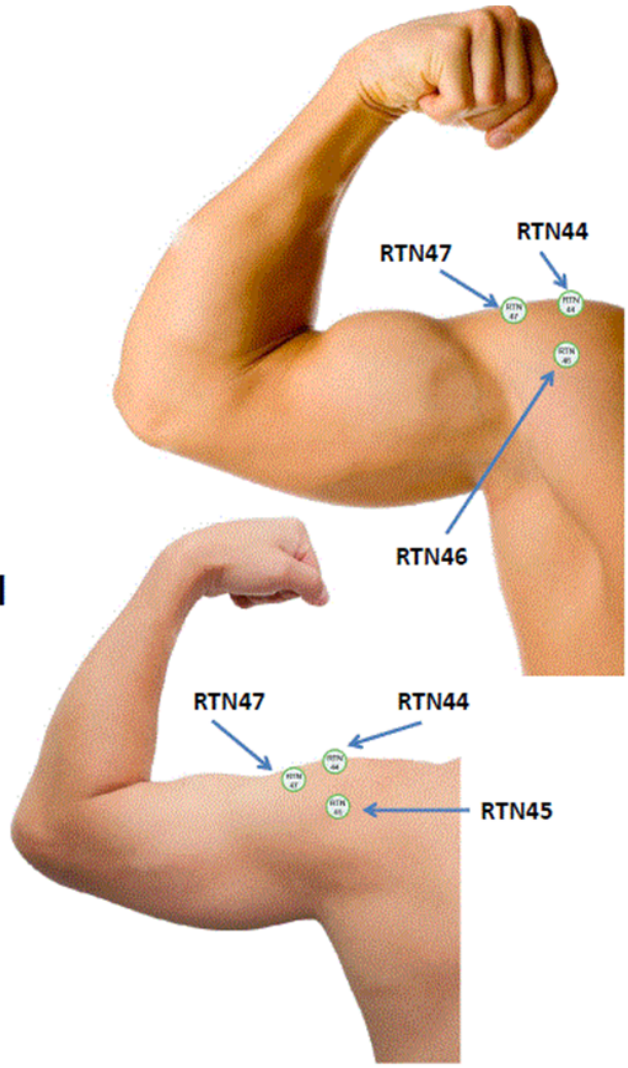

d

I

II

III
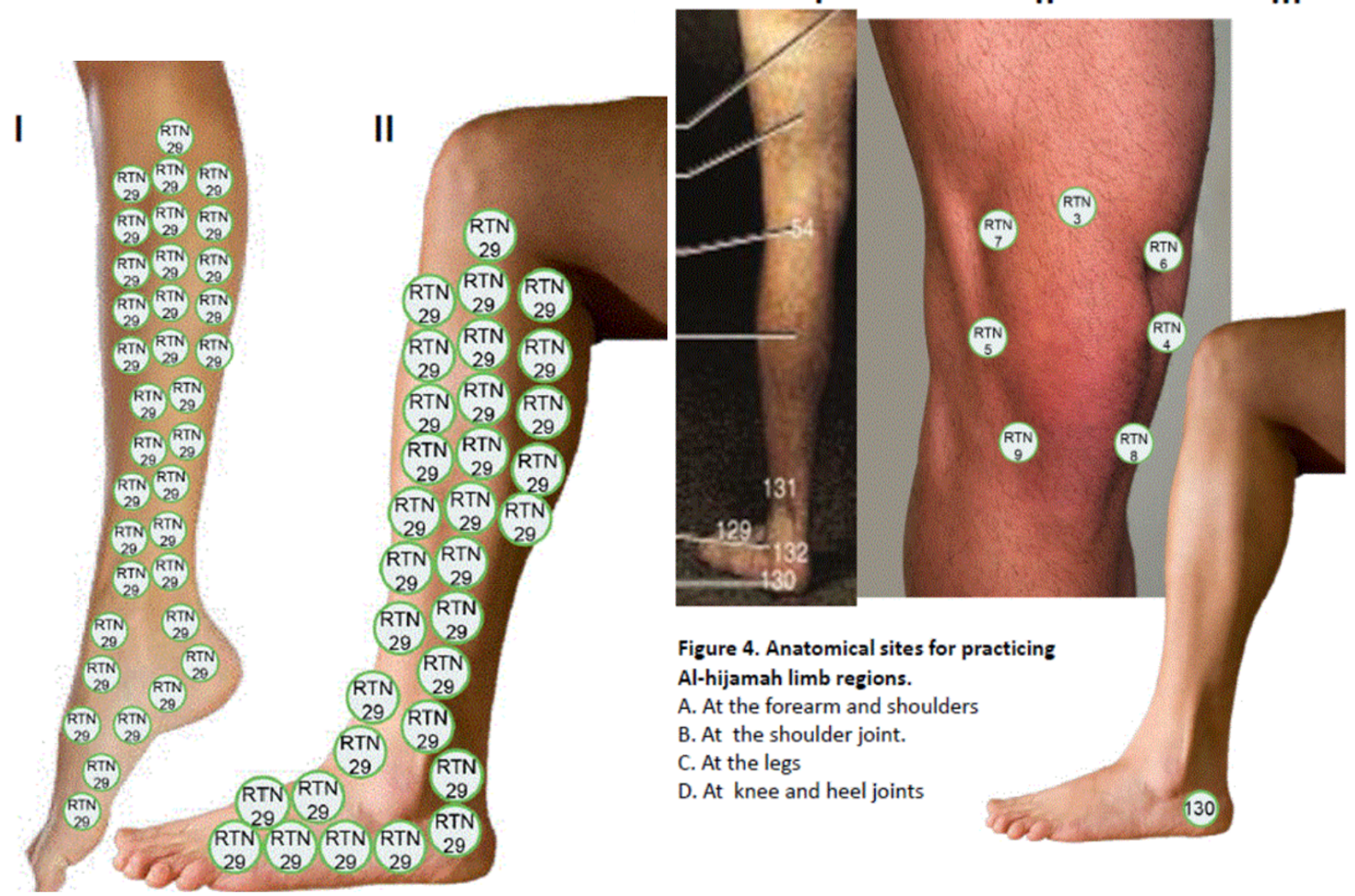

Figure 4: Anatomical sites for practicing Al-hijamah at points in upper and lower limbs. a. at ventral aspect of upper limb [72]. b. at dorsal aspect of upper limb [73]. c. at ventral aspect of knee joint [74]. d. at medial aspect of lower limb [75]. e. at lateral aspect of lower limb [76]. 


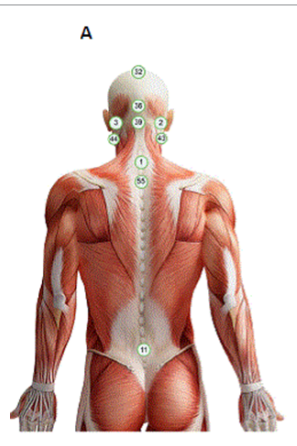

$\cdot 1-55$ $\cdot$ RTN1, RTN2, RTN16 $\cdot 2,3,11,32,36,39,43,44$

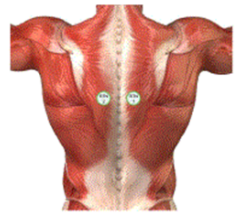

1-55

$\cdot$-RTN1-RTN2

$\cdot 9-10-11-12-13-49-120$

N.B. Sucking cups should b
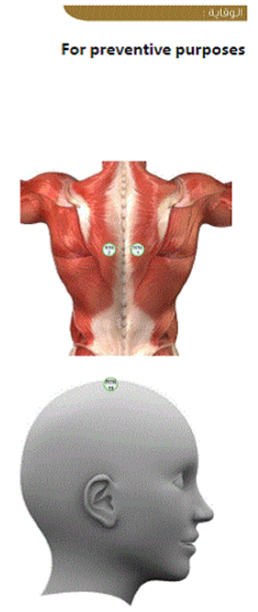
RTN3-RTN4-RTN5-RTN6 -RTN7-RTN8-

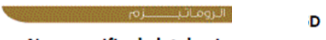

Non-specific skeletal pain
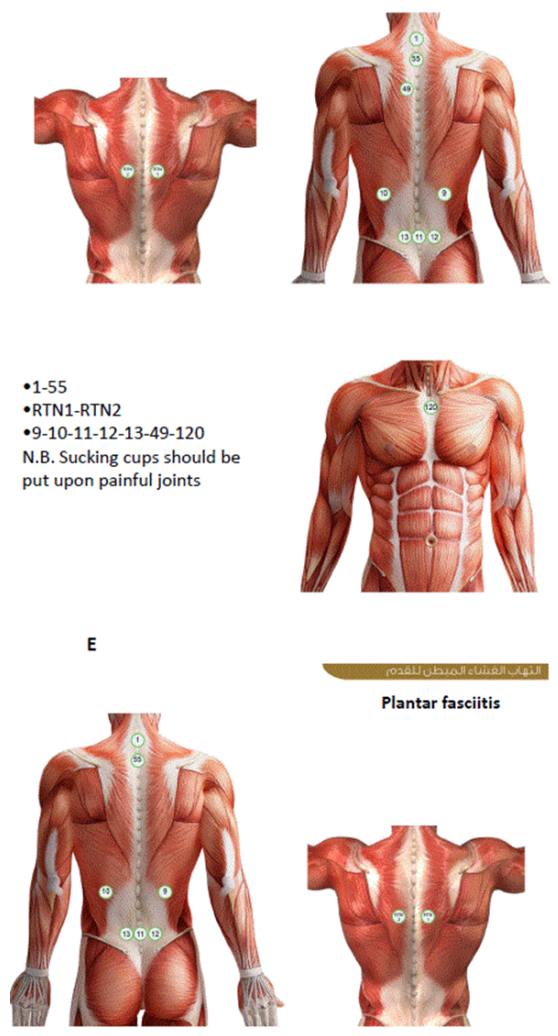

Plantar fasciitis

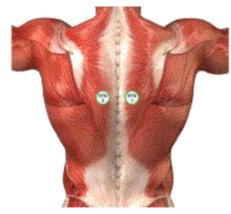

-1-55

•RTN1-RTN2

-9-10-11-12-13- 130

-Apply cups to painful foot regions

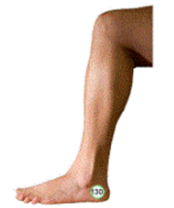

$1-55$

•9-10-11-12-13

- 53 (for right knee) or 54 (for left knee)

RTN9

N.B. Knee should be surrounded by putting 6-8 cups

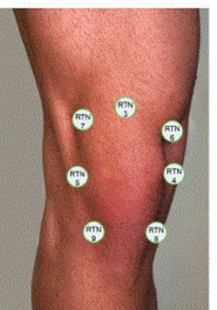

D

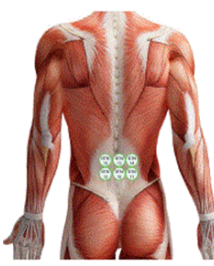

-11-12-13-26-27-51-52

- RTN10-RTN11-RTN12-RTN13-RTN14

RTN15

N.B. Putting

is advisable

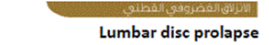

Lumbar disc prolapse
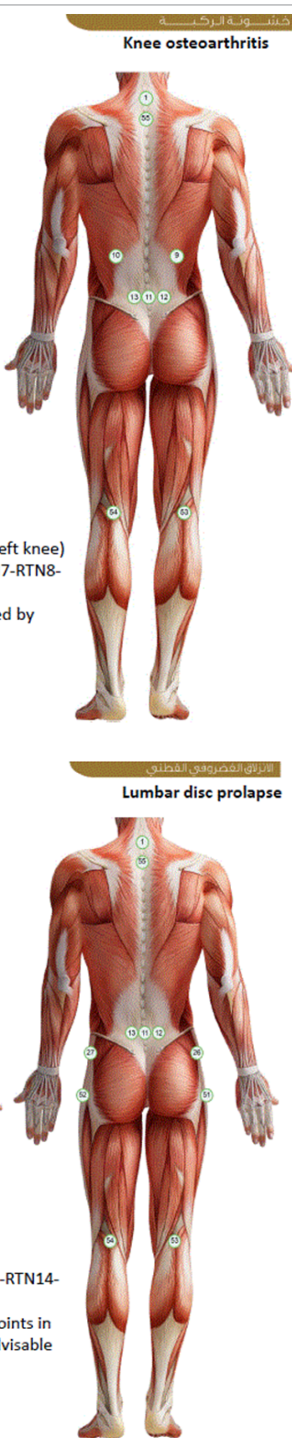

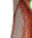
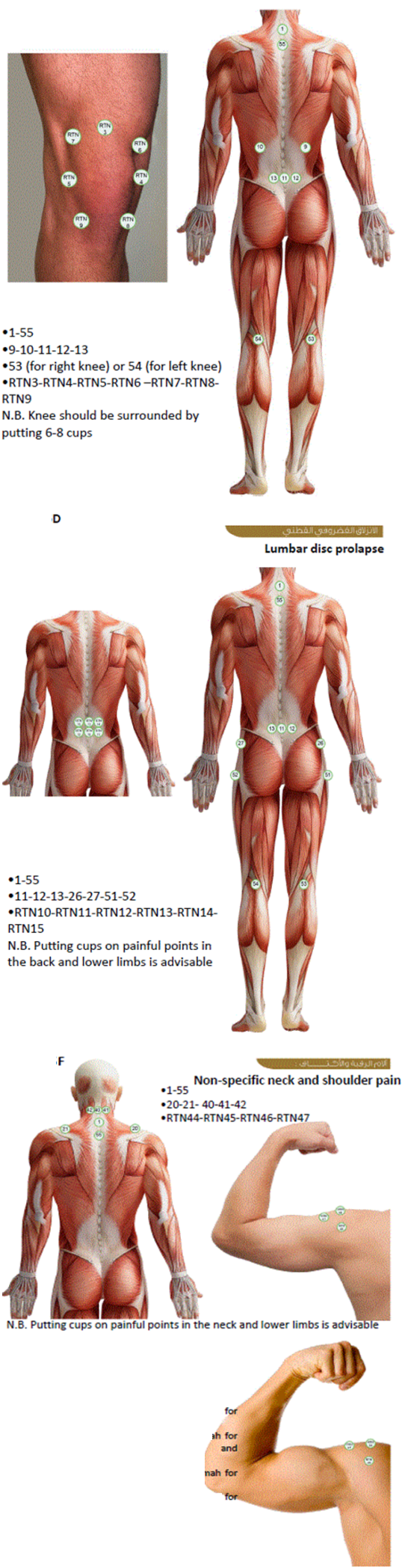

Figure 5: Anatomical sites for practicing Al-hijamah for treating Musculoskeletal pain conditions. a. Anatomical points for performing Al-hijamah for treating knee osteoarthritis. b. Anatomical points for performing Al-hijamah for treating simple arthralgia, arthritis and musculoskeletal pain. c. Anatomical points for performing Al-hijamah for treating lumbar disc prolapse. d. Anatomical points for performing Al-hijamah for treating neck and shoulder pain. e. Anatomical points for performing Al-hijamah for treating plantar fasciitis. 

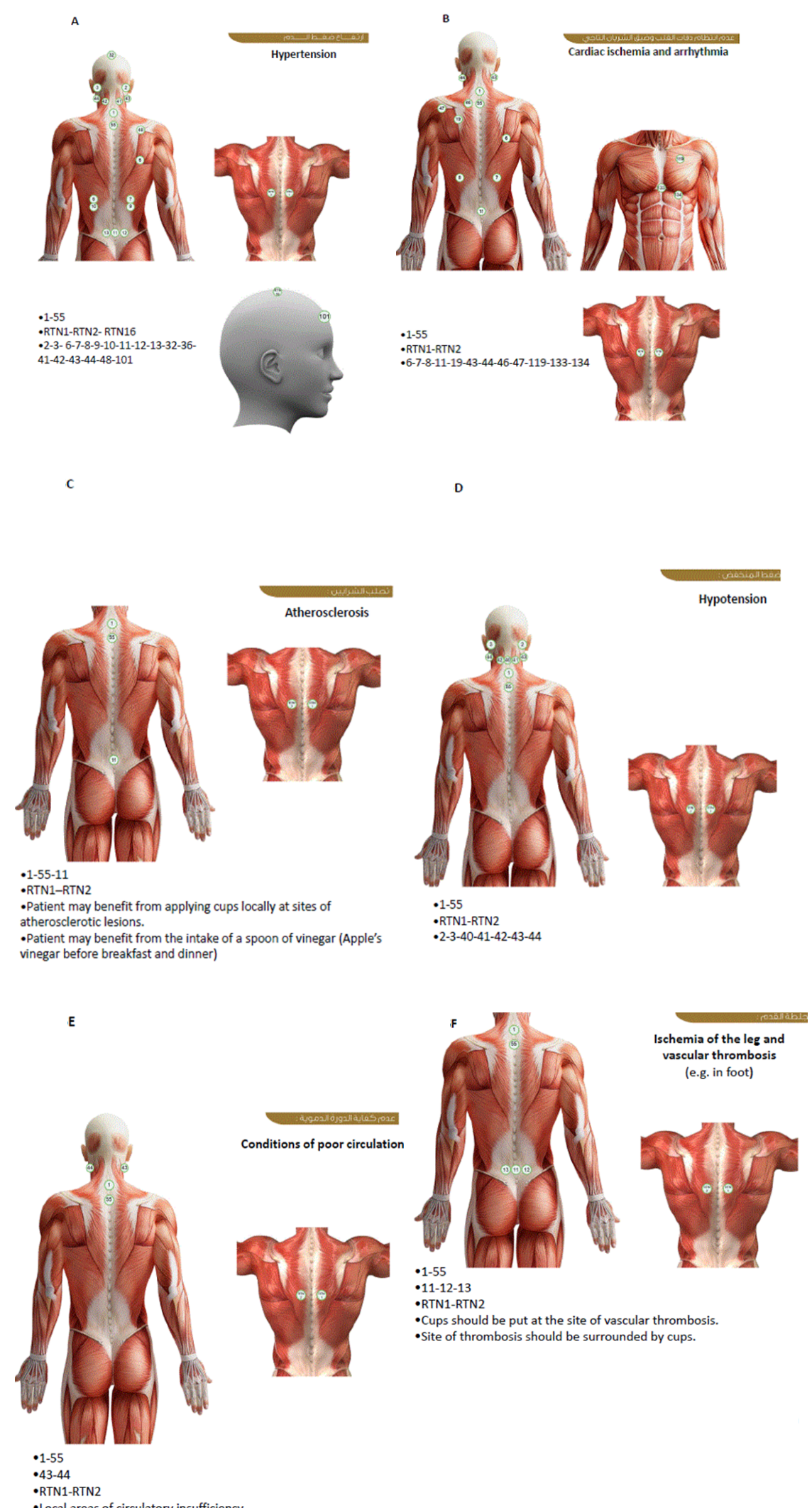

$\cdot 1-55$

-RTN1-RTN2

- Cups should be put at the site of vascular thrombosis.

- Site of thrombosis should be surrounded by cups.

Figure 6: Anatomical sites for practicing Al-hijamah for treating some cardiovascular diseases. a. Anatomical points for performing Al-hijamah for treating hypertension. b. Anatomical points for performing Al-hijamah for treating myocardial ischemia and arrhythmia. c. Anatomical points for performing Al-hijamah for treating atherosclerosis. d. Anatomical points for performing Al-hijamah for treating hypotension. 

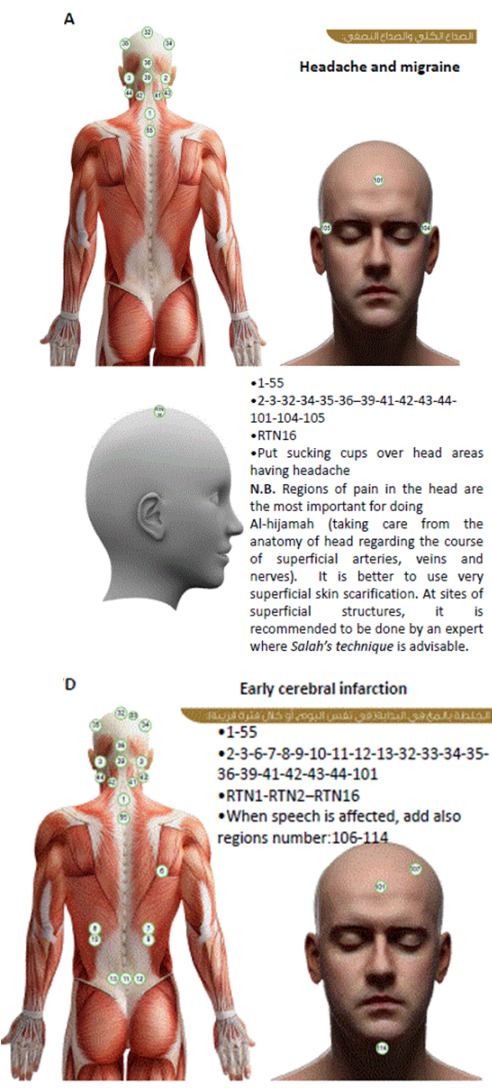

Early cerebral infarction
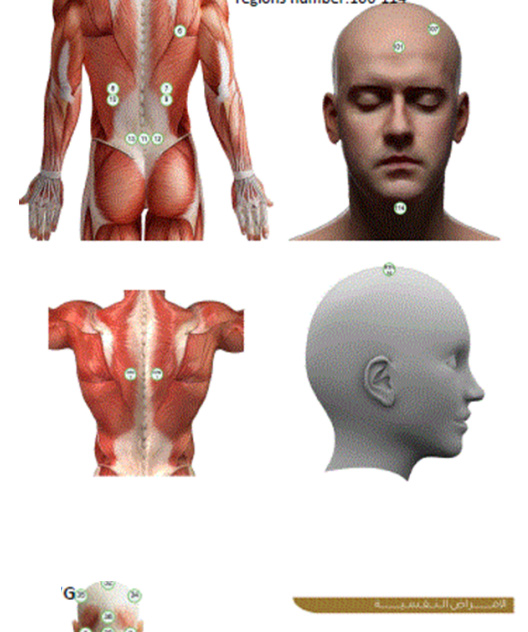

$\cdot 1-55$

Some psychiatric conditions

RTN1-RTN2-RTN16

2-3-6-11-32-34-35-36-39-41-42-4344-101
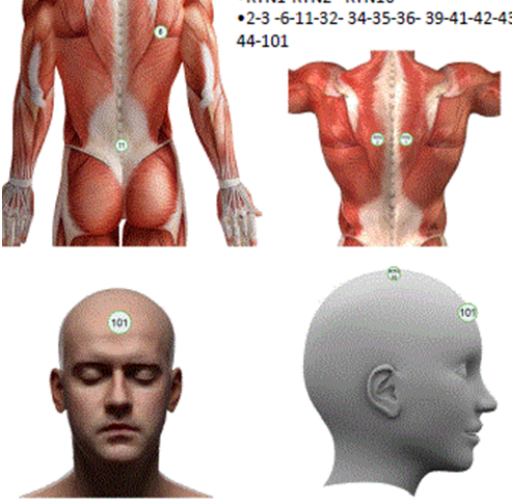
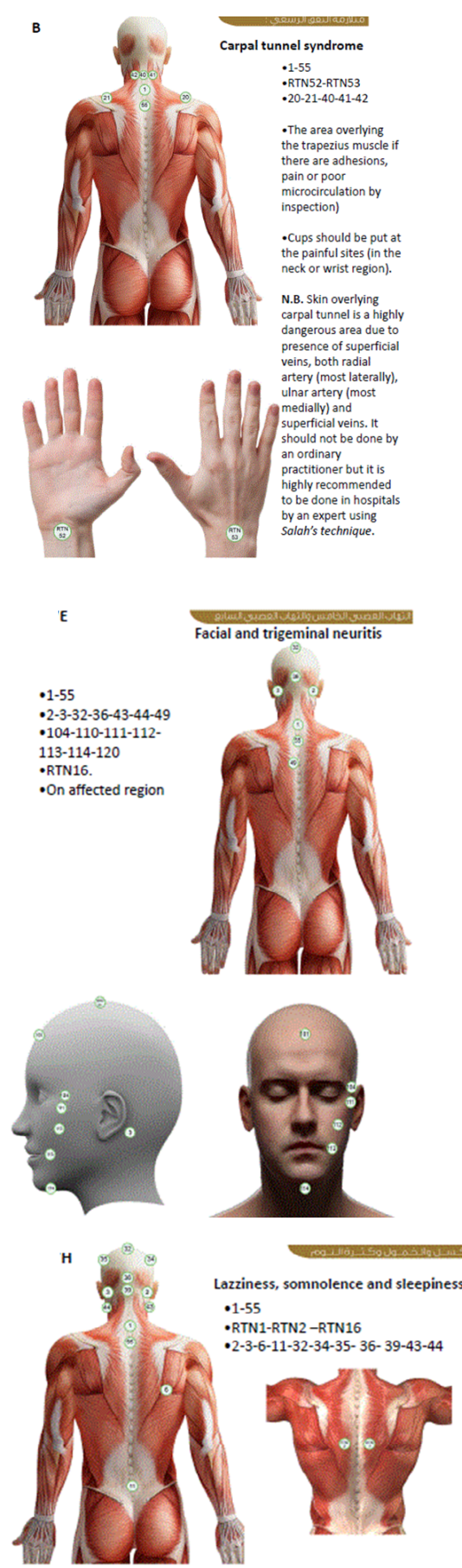

-RTN1-RTN2-RTN16

-2-3-6-11-32-34-35- 36- 39-43-44
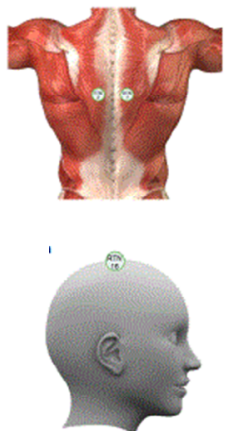

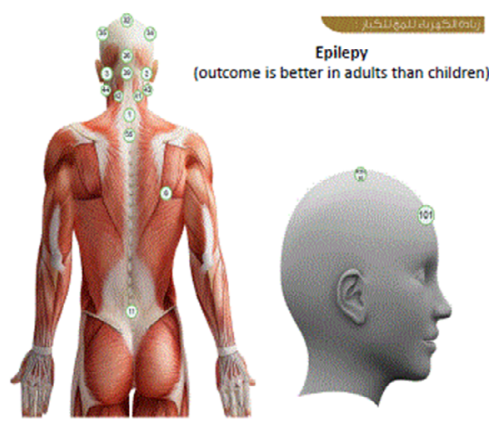

$\cdot 1-55$

$-2-3-6-11-32-34-35-36-39-41-42-43-44-101$

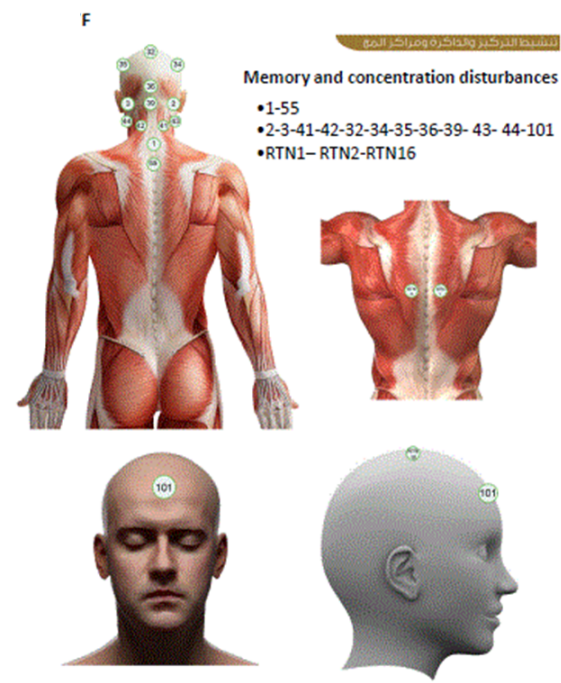

Figure 7: Anatomical sites for practicing Al-hijamah for treating some neuro-psychiatric conditions. a. Anatomical points for performing Al-hijamah for treating headache and migraine. b. Anatomical points for performing Al-hijamah for treating carpal tunnel syndrome. c. Anatomical points for performing Al-hijamah for treating epilepsy. d. Anatomical points for performing Al-hijamah for treating early cerebral infarction. e. Anatomical points for performing Alhijamah for treating trigeminal neuralgia, trigeminal neuritis and facial neuritis. f. Anatomical points for performing Al-hijamah for treating laziness, lassitude and somnolence. g. Anatomical points for performing Al-hijamah for treating impaired memory and concentration. h. Anatomical points for performing Al-hijamah for treating some psychiatric conditions. 

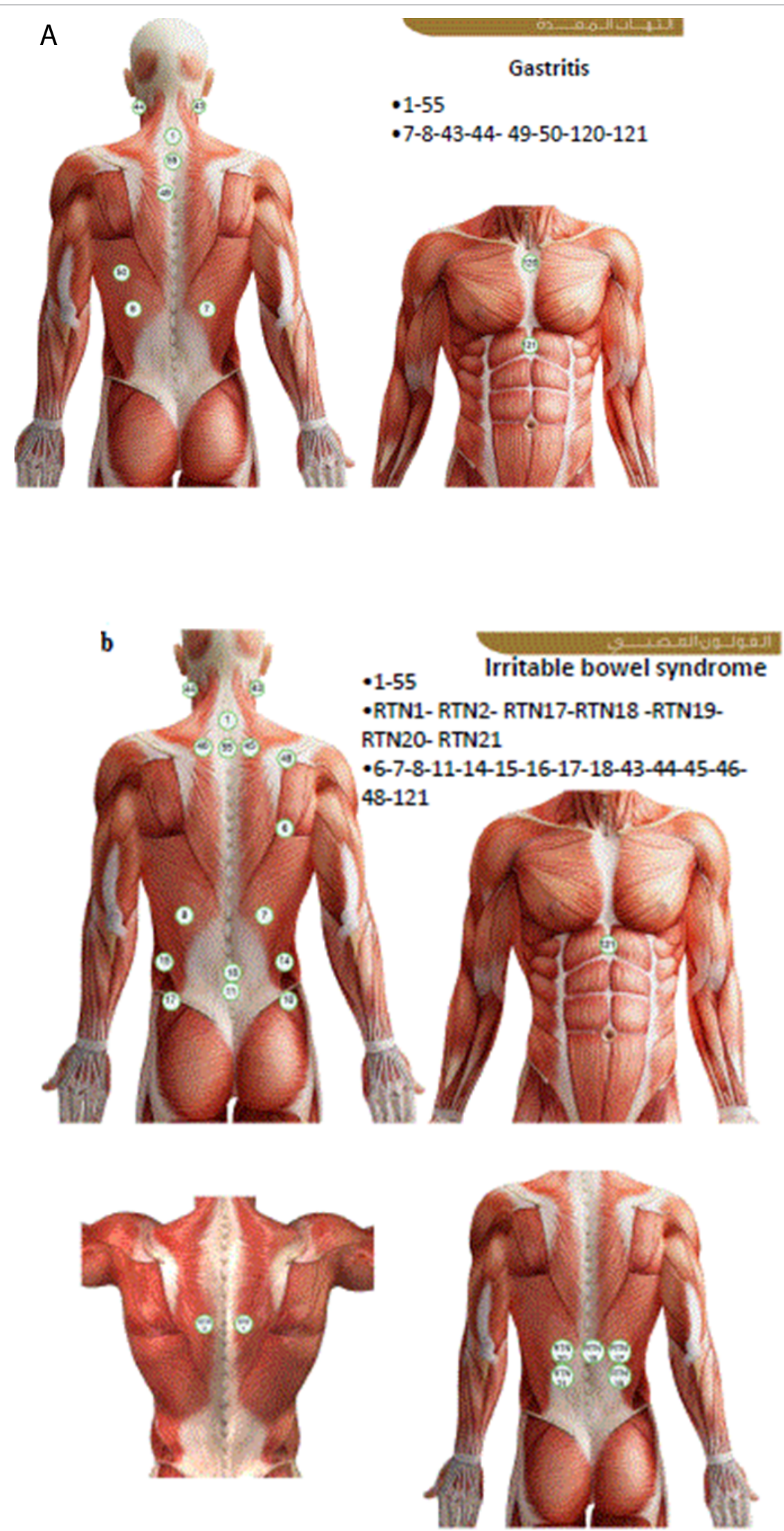

Figure 8: Anatomical sites for practicing Al-hijamah for treating some gastrointestinal diseases. a. Anatomical points for performing Al-hijamah for treating gastritis. b. Anatomical points for performing Al-hijamah for treating irritable bowel syndrome. 
Citation: Mahmoud HS, Abou-El-Naga M, Omar NAA, El-Ghazzawy HA, Fathy YM, et al. (2013) Anatomical Sites for Practicing Wet Cupping Therapy (Al-Hijamah): In Light of Modern Medicine and Prophetic Medicine. Altern Integ Med 2: 138. doi:10.4172/2327-5162.1000138

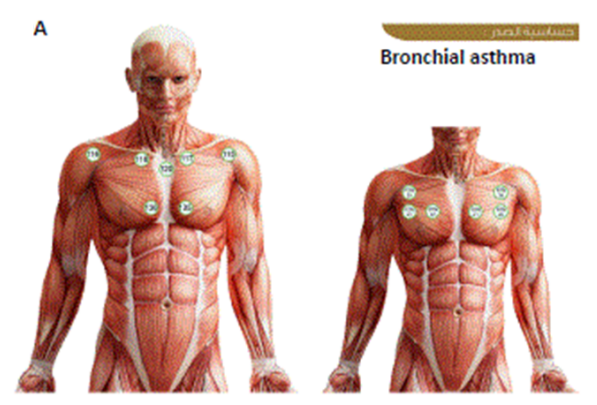

$\cdot 1-55$

-20-21-41-42-43-44-49-114-120 -RTN1-RTN2
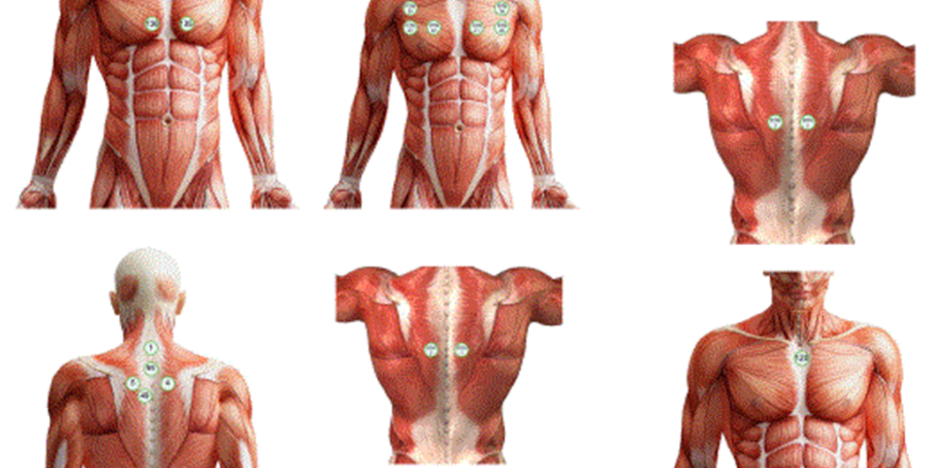

$\cdot 1-55$

-RTN1-RTN2-RTN38-RTN39-RTN40RTN41-RTN42-RTN43

-4-5-9-10-49

-115-116-117-118-120-135-136

-When there is an associated sinusitis,

Al-hijamah can be done at more than

pne session to include all the

anatomical sites.
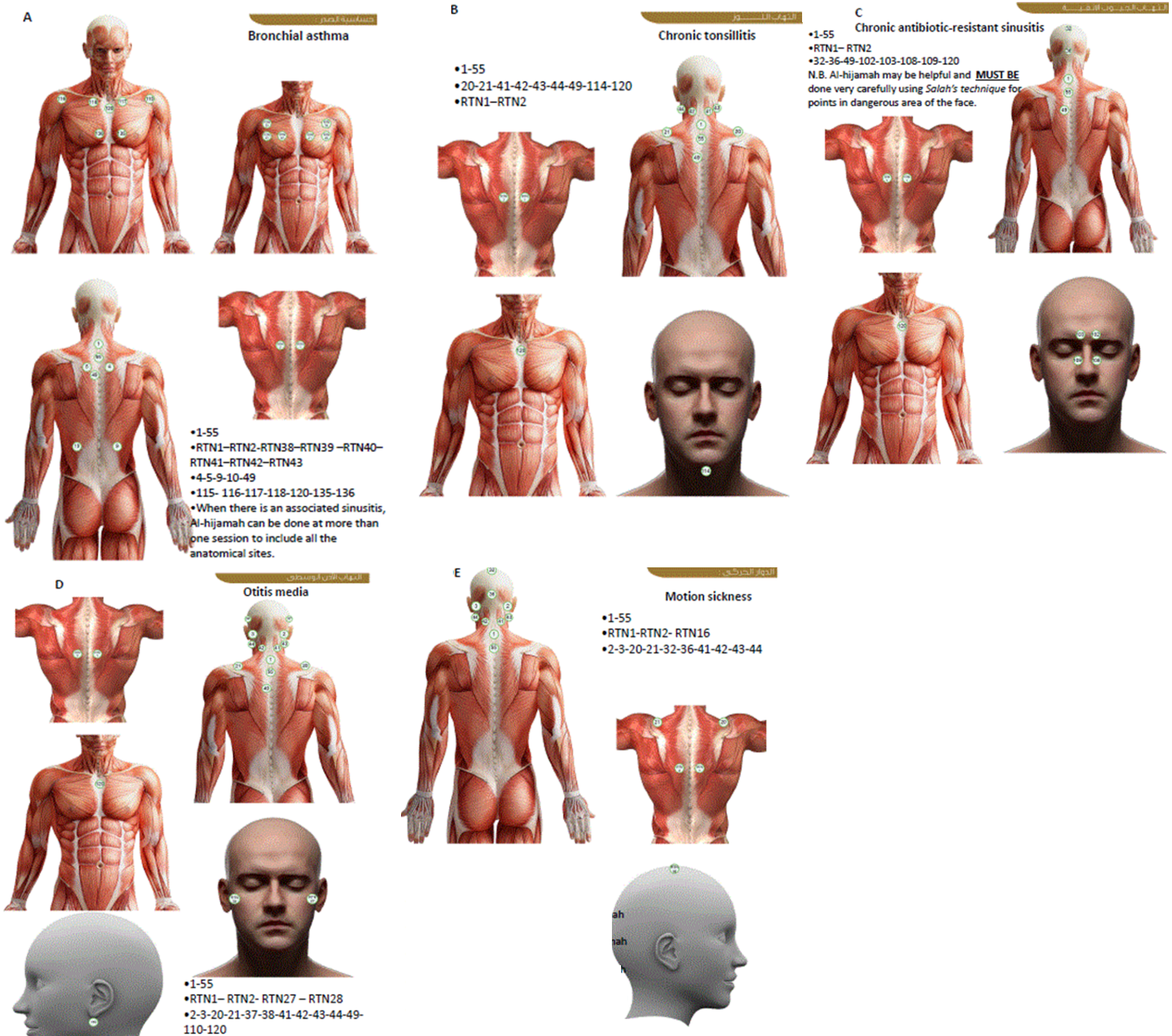

$1-55$

1-RTN2- RTN16

-2-3-20-21-32-36-41-42-43-44
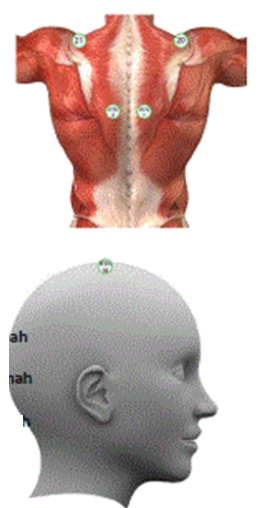

Figure 9: Anatomical sites for practicing Al-hijamah for treating respiratory and ENT diseases. a. Anatomical points for performing Al-hijamah for treating bronchial asthma. b. Anatomical points for performing Al-hijamah for treating motion sickness. c. Anatomical points for performing Al-hijamah for treating tonsillitis. d. Anatomical points for performing Al-hijamah for treating sinusitis. e. Anatomical points for performing Al-hijamah for treating otitis media. 
Citation: Mahmoud HS, Abou-El-Naga M, Omar NAA, El-Ghazzawy HA, Fathy YM, et al. (2013) Anatomical Sites for Practicing Wet Cupping Therapy (Al-Hijamah): In Light of Modern Medicine and Prophetic Medicine. Altern Integ Med 2: 138. doi:10.4172/2327-5162.1000138

A

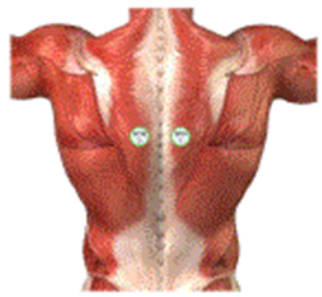

-1-55

-RTN1-RTN2 -RTN22 - RTN23-

RTN24- RTN25-RTN26

-41-42-43-44-49-120)

(N.B. Sucking cups should be put on skin overlying thyroid gland carefully using Salah's technique).
Thyroid dysfunction and autoimmunity
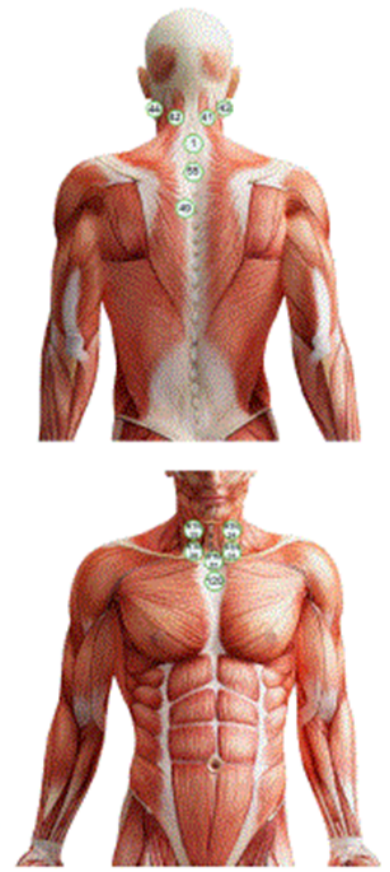

-1-55

-RTN1-RTN2

-9-10-11-12-13-28-29-30-31-121

-Put cups at the points of pain in the legs and feet and where urate crystals are deposited.
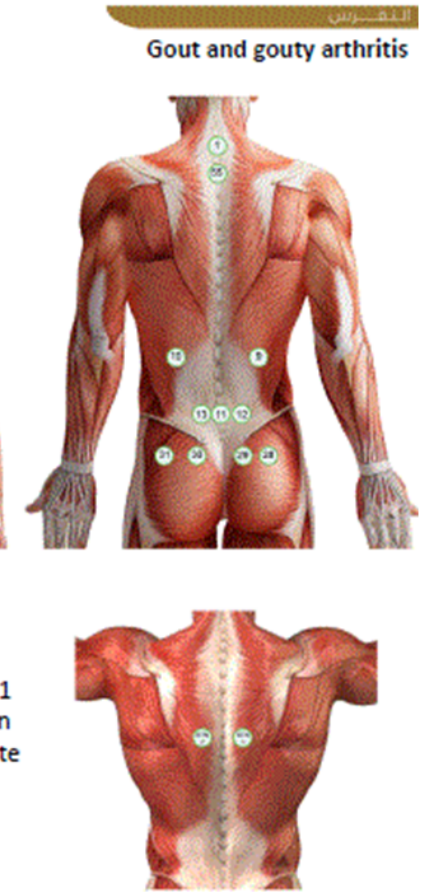
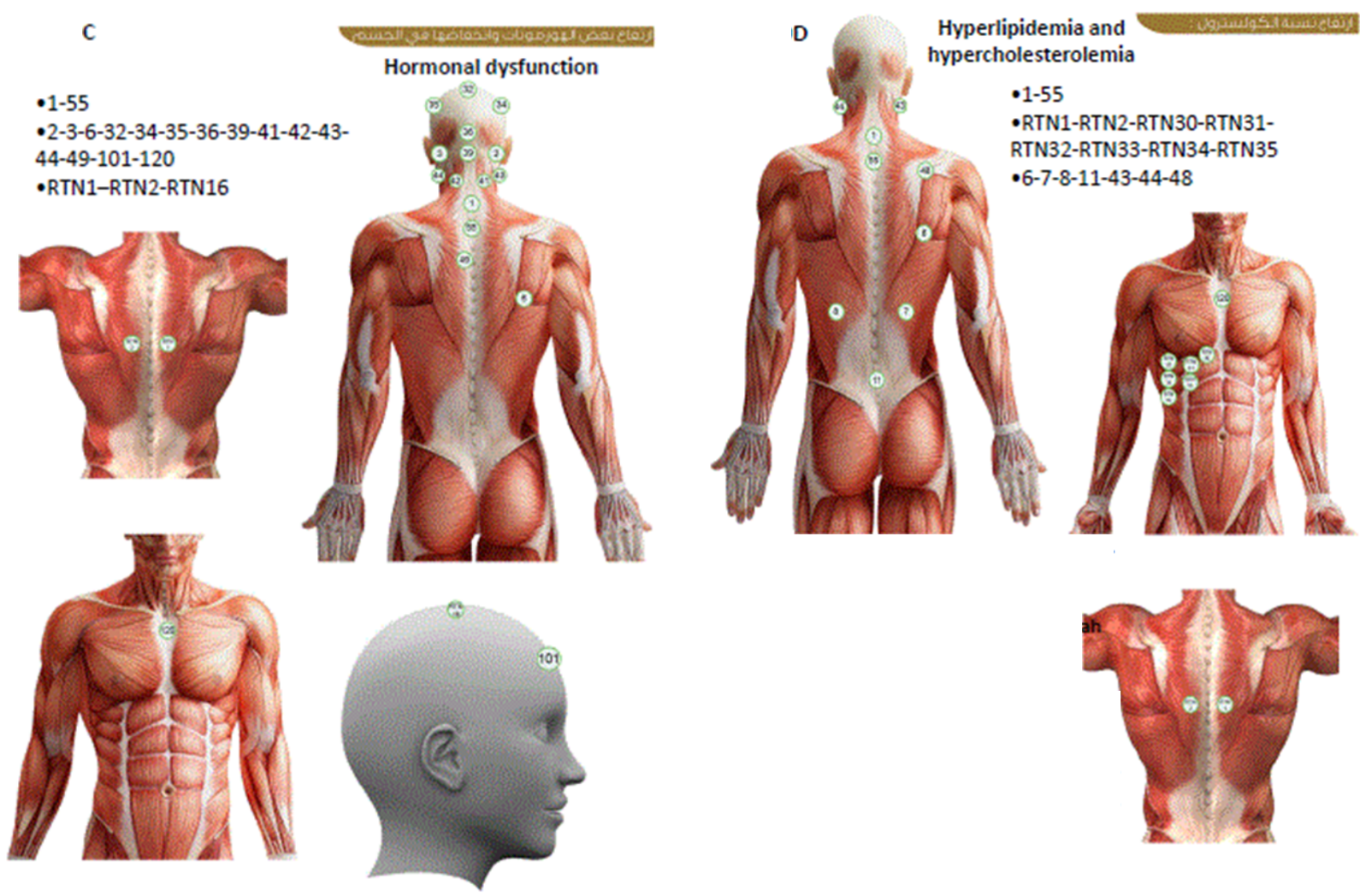

Figure 10: Anatomical sites for practicing Al-hijamah for treating metabolic conditions. a. Anatomical points for performing Al-hijamah for treating thyroid dysfunction b. Anatomical points for performing Al-hijamah for treating gout and gouty arthritis c. Anatomical points for performing Al-hijamah for treating conditions of hormonal dysfunction. d. Anatomical points for performing Al-hijamah for treating hypercholesterolemia. 

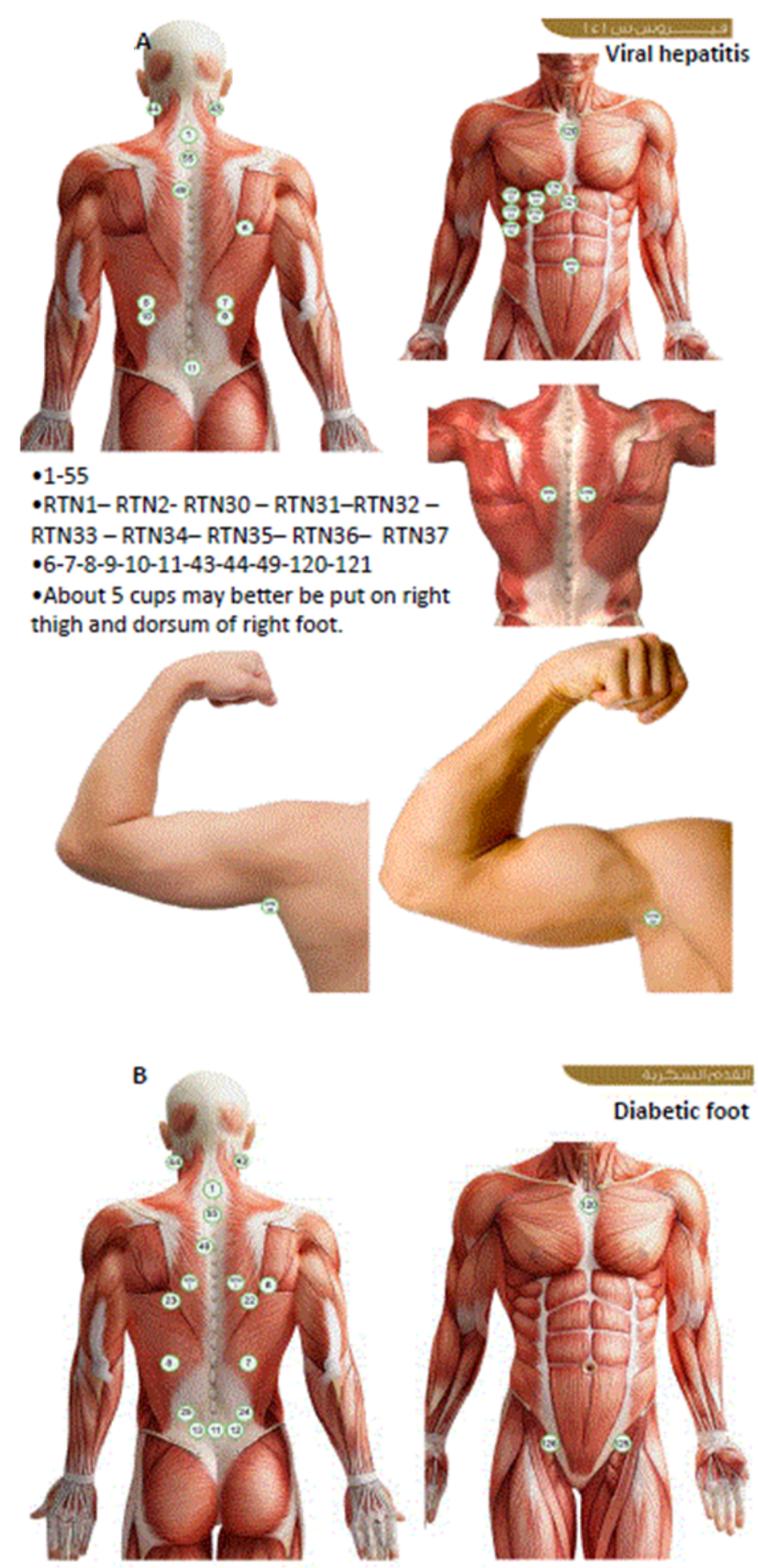

\section{$\bullet 1-55$}

-6-7-8-11-12-13-22-23-24-25-43-44.

$\cdot 125-126$

-RTN1 - RTN2-RTN29

N.B. Each case should be evaluated and

individualized. Vascular surgeon Must be consulted -RTN 29 is the moat important for clearance of interstitial fluids. Put as many cups as you can).

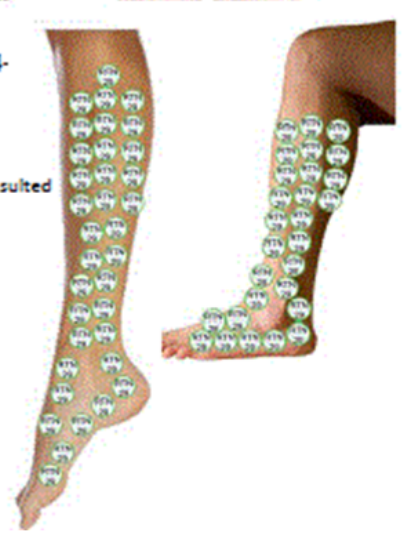

Figure 11: Anatomical sites for practicing Al-hijamah for treating infections and infectious diseases. a. Anatomical points for performing Al-hijamah for treating hepatitis viral infections $\mathrm{b}$. Anatomical points for performing Al-hijamah for treating diabetic foot. 
Citation: Mahmoud HS, Abou-El-Naga M, Omar NAA, El-Ghazzawy HA, Fathy YM, et al. (2013) Anatomical Sites for Practicing Wet Cupping Therapy (Al-Hijamah): In Light of Modern Medicine and Prophetic Medicine. Altern Integ Med 2: 138. doi:10.4172/2327-5162.1000138

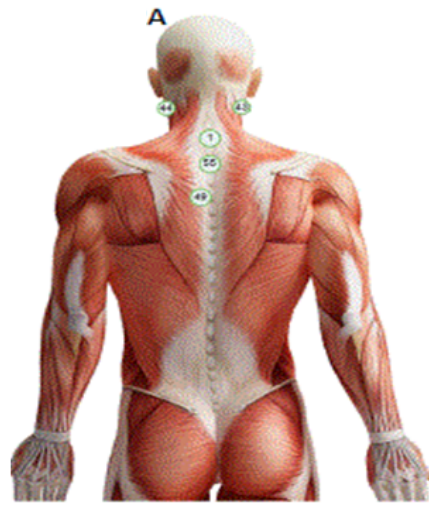

$\cdot 1-55$

-RTN1-RTN2

-43-44-49-120
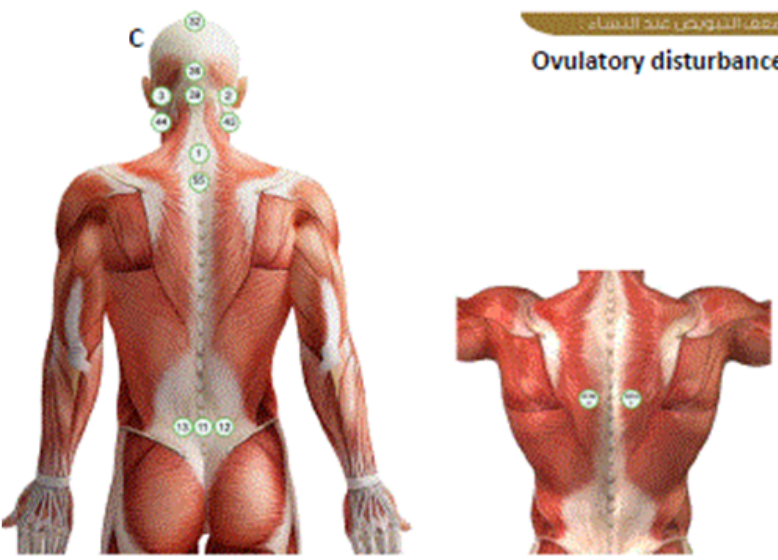

- $1-55$

- RTN1-RTN2-RTN48- RTN49RTN50- RTN51

- 2-3-11-12-13-32-36-39-43-44125-126
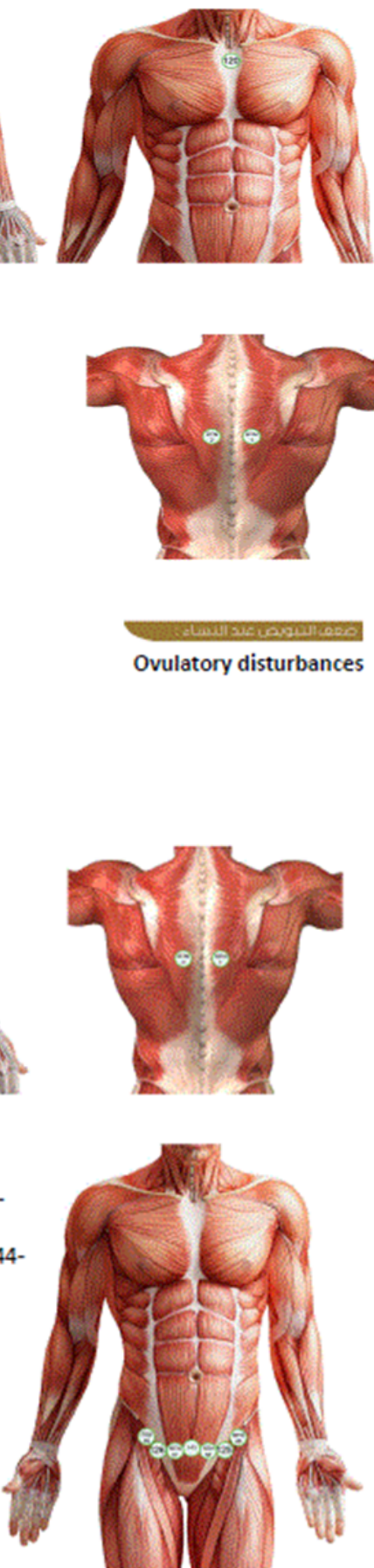

Conditions of impaired immunity

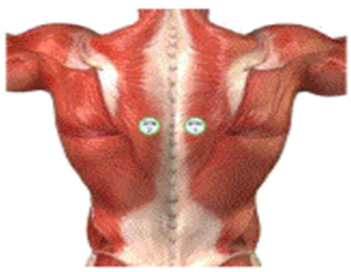

-1-55

2-3-9-10-11-32-34-35-36-41-4243-44-101-104-105 -RTN16
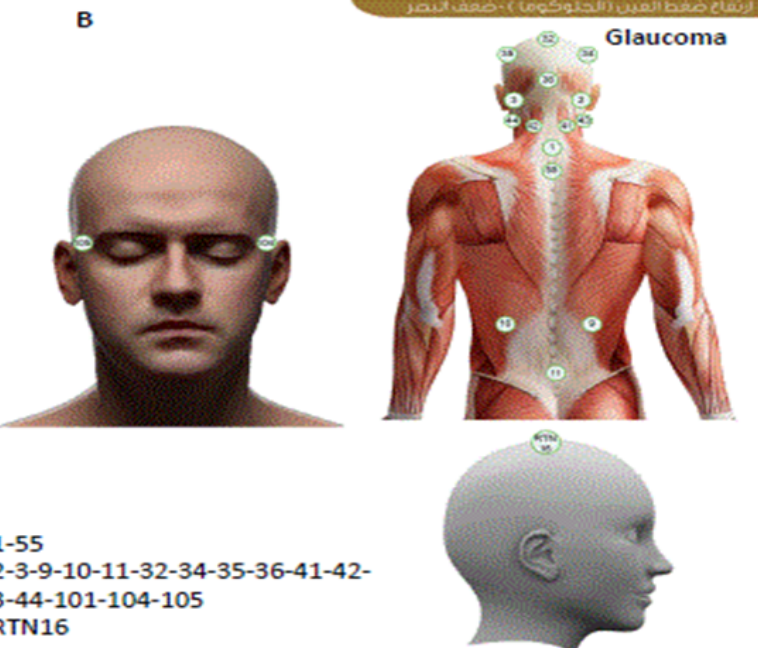

101

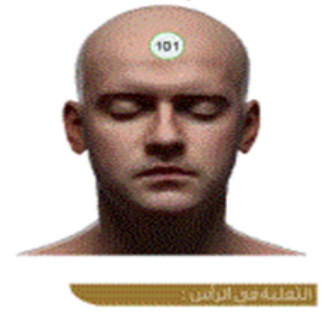

D

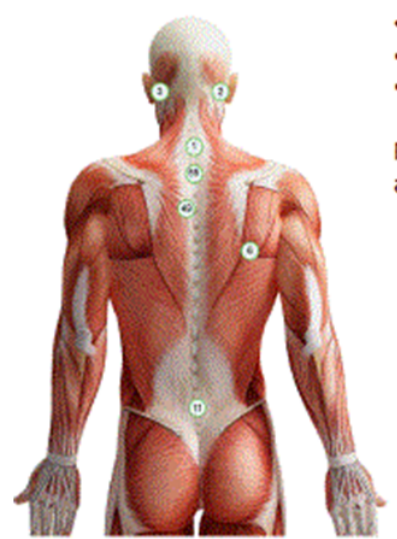

- 1-55

- RTN1-RTN2

- 2-3-6-11-49-120

N.B. Put sucking cups on localized areas of alopecia
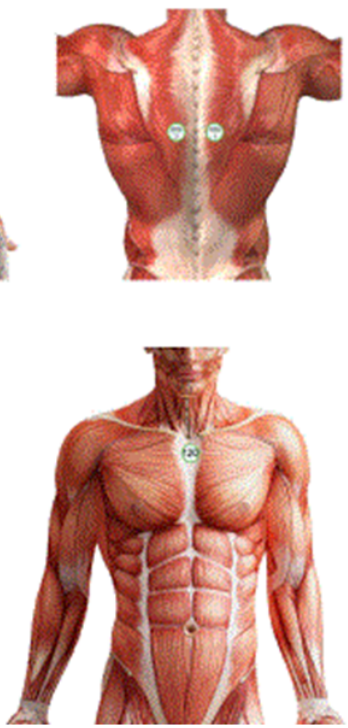

Figure 12: Anatomical sites for practicing Al-hijamah for treating some miscellaneous conditions. a. Anatomical points for performing Al-hijamah for treating conditions of decreased immunity b. Anatomical points for performing Al-hijamah for treating alopecia (localized alopecia). c. Anatomical points for performing Al-hijamah for treating glaucoma. 
Citation: Mahmoud HS, Abou-El-Naga M, Omar NAA, El-Ghazzawy HA, Fathy YM, et al. (2013) Anatomical Sites for Practicing Wet Cupping Therapy (Al-Hijamah): In Light of Modern Medicine and Prophetic Medicine. Altern Integ Med 2: 138. doi:10.4172/2327-5162.1000138

Page 28 of 30

a pure medical atmosphere (as it is done in China and Germany now) to close the way in face of unqualified malpractitioners. Ministries of health worldwide and in Islamic countries are invited to allow and encourage the practice of Al-hijamah officially in hospitals (as it is done in China and Germany now) to benefit patients, relieve pain and to decrease human suffering. Potential challenges against practicing $\mathrm{Al}-$ hijamah in the past were lack of a scientific rational to explain how Alhijamah and cupping therapy may treat different diseases. However, that was solved through introducing Taibah mechanism (by Salah M. El Sayed) [1] that explained on scientific and medical bases how beneficial is Al-hijamah and its therapeutic and health benefits. Skillful practitioners of Al-hijamah can easily be qualified immediately after recognizing Al-hijamah as a formal modality of treatment in hospitals in the western world and worldwide. Hijamatology should be studied at medical schools at the undergraduate and postgraduate levels to enrich medical background of students and physicians regarding Al-hijamah. Until that goal is achieved, plastic surgeons are the best medical practitioners to practice Al-hijamah. Qualifying non-medical practitioners for Al-hijamah is strongly recommended to improve their scientific and practical levels.

\section{Acknowledgements}

Our sincere thanking is offered to the helpful revisions, nice additions and corrections made by Dr. Jameel Awwad Sulami, (H.D., Researcher \& Consultan in Prophetic Medicine, Doctor of Hijamatolojy, Holistic and Functional Medicine Specialist from Turkey). Efforts of Dr. Jameel deserve appraisal in honestly serving prophetic medicine. Dr. Jameel offered big efforts as an advisor for this work. We are so grateful to the library of Sohag faculty of medicine, Sohag University, Egypt for providing the internet facility and helpful textbooks. We are so grateful to Haj Gamal Mohamed Atwa for kindly supporting the publication fees of the article.

\section{References}

1. El Sayed SM, Mahmoud HS, Nabo MMH (2013) Medical and scientific bases of wet cupping therapy (Al-hijamah): in light of modern medicine and prophetic medicine. Altern Integ Med 2: 1-16.

2. Chirali IZ (1999) The cupping procedure. Traditional Chinese Medicine Cupping Therapy. London, Churchill Livingstone 73-86.

3. Shaheed Abd Hameed Omar (2009) Al-hijamah (cupping therapy): Sunnah and therapy (in Arabic). Dar Ommah. Jeddah.

4. Cao H, Li X, Liu J (2012) An updated review of the efficacy of cupping therapy. PLoS One 7: e31793.

5. Loukas M, Saad Y, Tubbs RS, Shoja MM (2010) The heart and cardiovascular system in the Qur'an and Hadeeth. Int J Cardiol 140: 19-23.

6. Al-Jauziyah IIQ (1999) Prophetic Medicine (Healing with the Medicine of the Prophet Peace be upon Him). Fordham University, Darussalam Publishers \& Distributor.

7. Al-Zahaby MA (1940) Prophetic medicine. (3rdedn), Dar Ehiaa Al-Oloum (house for reviving sciences).

8. Falagas ME, Zarkadoulia EA, Samonis G (2006) Arab science in the golden age (750-1258 C.E.) and today. FASEB J 20: 1581-1586.

9. Leibowitz JO (1967) Studies in the history of alcoholism. II. Acute alcoholism in ancient Greek and Roman medicine. Br J Addict Alcohol Other Drugs 62 83-86

10. Thomas PH (1959) In Pursuit of Ancient Surgical and Medical Instruments. $J$ Coll Gen Pract Res News 12: 397-407.

11. Dirckx JH (1987) A little lexicon of archaic and obsolete medical terms. Am J Dermatopathol 9: 76-79.

12. Eoin O'Brien (1978) Reading for pleasure. Br Med J 1: 1408-1412.

13. Abdel-Halim RE, Alkattan KM (2012) Introducing medical humanities in the medical curriculum in Saudi Arabia: A pedagogical experiment. Urol Ann 4: 73-79.

14. Al-Bukhari MI (1996) The English Translation of Sahih Al Bukhari with the Arabic Text (9 Volume Set). Translated by Muhammad Muhsin Khan, Al-
Saadawi Publications, Book 71, hadeeth 584.

15. Al-Bukhari MI (1996) The English Translation of Sahih Al Bukhari with the Arabic Text (9 Volume Set). Translated by Muhammad Muhsin Khan, AlSaadawi Publications, Book of medicine, chapter of treatment using happah sawdaa (nigella sativa), hadeeth 2215 .

16. Al-Bukhari MI (1996) The English Translation of Sahih Al Bukhari with the Arabic Text (9 Volume Set). Translated by Muhammad Muhsin Khan, AlSaadawi Publications, Book of medicine, chapter of treatment using Al-cost Al-bahri and Al-cost Al-hindi, hadeeth 2214.

17. Alkalim Al-Tayeb AAS, Ibn Taimiah (1987) Hadeeth number 213. Al-maarif library, Riyadh.

18. Haouari N, Wood C, Griffiths G, Levene M (1995) The analgesic effect of sucrose in full term infants: a randomised controlled trial. BMJ 310: 1498-1500.

19. Katme AM (1995) Analgesic effects of sucrose were known to the prophet. BM 311: 1169

20. Markestad T (1997) Use of sucrose as a treatment for infant colic. Arch Dis Child 76: 356-357.

21. Salem SA, Hegazi SM (1971) Chemical composition of the Egyptian dry dates. J Sci Food Agric 22: 632-633.

22. Al-Albani. Sahih and daeef sonan Al-termezy (2008) Dar Al-Maarif library, Riyadh, Saudi Arabia. Hadeeth number 1845.

23. Al-Bukhari MI (1996) The English Translation of Sahih Al Bukhari with the Arabic Text (9 Volume Set), Book of medicine, chapter of talpinah for patient, hadeeth 5689, Al-Saadawi Publications.

24. Al-Albani (2008) Sahih, Daeef sonan Al-termez, Hadeeth number 1757, Dar Al-Maarif library, Riyadh, Saudi Arabia.

25. Al-Bukhari MI (1996) The English Translation of Sahih Al Bukhari with the Arabic Text ( 9 Volume Set), Book of medicine, chapter of Mann is a cure for eye diseases, hadeeth 5708, Al-Saadawi Publications.

26. Al-Albani (2008) Sahih and daeef sonan Ibn Majah. Hadeeth number 3457, Dar Al-Maarif library, Riyadh, Saudi Arabia.

27. Al-Albani MN (1996) Series of correct hadeeths. (1stedn). Library of knowledge for publication 6: 1056

28. Al-Bukhari MI (1996) The English Translation of Sahih Al Bukhari with the Arabic Text (9 Volume Set), Book of foods, hadeeth number 5440, Al-Saadawi Publications.

29. Al-Bukhari MI (1996) The English Translation of Sahih Al Bukhari with the Arabic Text (9 Volume Set), Book of rokya (protective supplications), hadeeth number 5745, Al-Saadawi Publications.

30. Sahih AA, Al-termezy DS (2008) Hadeeth number 1851, Dar Al-Maarif library, Riyadh, Saudi Arabia.

31. Al-Bukhari MI (1996) The English Translation of Sahih Al Bukhari with the Arabic Text ( 9 Volume Set). Translated by Muhammad Muhsin Khan, AlSaadawi Publications, Book of Fridays, hadeeth number 888.

32. Al-Albani. Sahih and daeef sonan Ibn Majah, Hadeeth number 3436 , Dar AlMaarif library, Riyadh, Saudi Arabia.

33. Ahmed KS (2008) Arabic Medicine: Contributions and Influence. The Proceedings of the 17th Annual History of Medicine Days, Health Sciences Centre, Calgary, AB.

34. Al-Albani MN (1996) Series of correct hadeeths. (1stedn), Library of knowledge for publication 4: 174.

35. Aung SKH (2002) Sexual Dysfunction: A Modern Medical Acupuncture Approach. Medical Acupuncture 13.

36. Wan XW (2007) Clinical observation on treatment of cervical spondylosis with combined acupuncture and cupping therapies. Journal of Acupuncture and Tuina Science 5: 345-347

37. Raison J, Achimastos A, Asmar R, Simon A, Safar M (1986) Extracellular and interstitial fluid volume in obesity with and without associated systemic hypertension. Am J Cardiol 57: 223-226.

38. Zarei M, Hejazi S, Javadi SA, Farahani H (2012) The efficacy of wet cupping in the treatment of hypertension. ARYA Atherosclerosis 8: 1-4 
Citation: Mahmoud HS, Abou-El-Naga M, Omar NAA, El-Ghazzawy HA, Fathy YM, et al. (2013) Anatomical Sites for Practicing Wet Cupping Therapy (Al-Hijamah): In Light of Modern Medicine and Prophetic Medicine. Altern Integ Med 2: 138. doi:10.4172/2327-5162.1000138

Page 29 of 30

39. Gavras I, Gavras H (2012) 'Volume-expanded' hypertension: the effect of fluid overload and the role of the sympathetic nervous system in salt-dependent hypertension. J Hypertens 30: 655-659.

40. Swartz MN, Pasternack MS. Principles and Practice of Infectious Diseases. Cellulitis and subcutaneous tissue infections. (6thedn). Elsevier Churchill Livingstone, Philadelphia 1178-1180.

41. Quinn PJ, Markey BK, Leonard FC, Hartigan P, Fanning S, et al. (2012) Veterinary microbiology and microbial disease. (2ndedn). Chichester, West Sussex, UK: Wiley-Blackwell 170.

42. Van Amersfoort ES, Van Berkel TJ, Kuiper J (2003) Receptors, mediators, and mechanisms involved in bacterial sepsis and septic shock. Clin Microbiol Rev 16: $379-414$

43. Ahmed A, Khan RA, Ali AA, Ahmed M, Mesaik MA (2011) Effect of wet cupping therapy on virulent cellulitis secondary to honey bee sting-a case report. Journal of Basic and Applied Sciences 7: 123-125.

44. Hassan ali SH, Oyoo GO (2011) Osteoarthritis: A look at pathophysiology and approach to new treatments: East African Orthopaedic Journal.

45. Ahmadi A, Schwebel DC, Rezaei M (2008) The efficacy of wet-cupping in the treatment of tension and migraine headache. Am J Chin Med 36: 37-44.

46. Sahih AA, Dawood DSA (2007) Hadeeth number 3485, Dar Al-Maarif library, Riyadh, Saudi Arabia

47. Sahih Moslim (2004) Berut, Hadeeth 1577, Asria library

48. Al-Bukhari MI (1996) The English Translation of Sahih Al Bukhari with the Arabic Text (9 Volume Set), Book of medicine, hadeeth number 5699, AlSaadawi Publications.

49. Sahih AA, Dawood DSA (2007) Hadeeth number 2012, Dar Al-Maarif library, Riyadh, Saudi Arabia.

50. Sahih AA, Dawood DSA (2007) Hadeeth number 3864, Dar Al-Maarif library, Riyadh, Saudi Arabia.

51. Sahih AA, Majah DSI (2008) Hadeeth number 3485, Dar Al-Maarif library, Riyadh, Saudl Arabia.

52. Sahih AA, Al-Nasaaee DS (2008) Hadeeth number 2849, Dar Al-Maarif library, Riyadh, Saudl Arabia.

53. Al-Bukhari MI (1996) The English Translation of Sahih Al Bukhari with the Arabic Text. Book of medicine, Chapter of Al-hijamah for treating headache and migrane. Hadeeth number 5701, Al-Saadawi Publications.

54. Al-Albani (2007) Sahih and daeef sonan Abo Dawood, Hadeeth number 3863 Dar Al-Maarif library, Riyadh, Saudl Arabia.

55. AL-Shamma YM, Abdil Razzaq A (2009) Al-Hijamah Cupping Therapy. Kufa Med J 12.

56. Messlinger K, Fischer MJ, Lennerz JK (2011) Neuropeptide effects in the trigeminal system: pathophysiology and clinical relevance in migraine. Keio $\mathrm{J}$ Med 60: 82-89.

57. Zhang Z (1997) Observation on therapeutic effects of blood-letting puncture with cupping in acute trigeminal neuralgia. J Tradit Chin Med 17: 272-274.

58. Hayashi D, Hamilton B, Guermazi A, de Villiers R, Crema MD, et al. (2012) Traumatic injuries of thigh and calf muscles in athletes: role and clinical relevance of MR imaging and ultrasound. Insights Imaging 3: 591-601.

59. Fayad LM, Carrino JA, Fishman EK (2007) Musculoskeletal infection: role of CT in the emergency department. Radiographics 27: 1723-1736.

60. Lenin Babu V, Rana MM, Arumilli BR, Dean T, Brown C, et al. (2007) Chronic expanding haematomas with interesting presentations. lowa Orthop J 27: 108111

61. Mentzel T, Goodlad JR, Smith MA, Fletcher CDM. Ancient Haematoma: A unifying concept for a post-traumatic lesion mimicking an aggressive soft tissue neoplasm. Modern Pathology 10: 334-40.

62. O'Keefe RJ, O'Connell JX, Temple HT, Scully SP, Kattapuram SV, et al. (1995) Calcific myonecrosis. A late sequela to compartment syndrome of the leg. Clin Orthop Relat Res 205-213.

63. Sahih AA, Abo Dawood DS (2007) Hadeeth number 3858, Dar Al-Maarif library, Riyadh, Saudi Arabia.
64. Huber R, Emerich M, Braeunig M (2011) Cupping - is it reproducible? Experiments about factors determining the vacuum. Complement Ther Med 19: 78-83.

65. Ahmed Hefny (1990) Teaching the treatment using Al-hjamah (In Arabic).

66. Saladin KS (2003) Anatomy \& Physiology: The Unity of Form and Function. Support and movement. (3rdedn), The McGraw- Hill companies 32.

67. Carmine D (2010) Clemente. Anatomy: a regional atlas of the human body. (6thedn), Lippincott Williams \& Wilkins, Baltimore, USA 518

68. Saladin KS (2003) Anatomy \& Physiology: The Unity of Form and Function. Support and movement. (3rdedn), The McGraw- Hill companies 245.

69. Saladin KS (2003) Anatomy \& Physiology: The Unity of Form and Function. Support and movement. (3rdedn), The McGraw- Hill companies 246.

70. Saladin KS (2003) Anatomy \& Physiology: The Unity of Form and Function Support and movement. (3rdedn), The McGraw- Hill companies 390.

71. Clemente CD (2010) Anatomy: a regional atlas of the human body. (6thedn) Surface anatomy of the thoracic and abdominal walls in a young male. Lippincott Williams \& Wilkins, Baltimore, USA 371.

72. Clemente CD (2010) Anatomy: a regional atlas of the human body. (6thedn), Surface anatomy of the right upper limb (anterior aspect). Lippincott Williams \& Wilkins, Baltimore, USA.

73. Clemente CD (2010) Anatomy: a regional atlas of the human body. (6thedn), Surface anatomy of the right upper limb (posterior aspect). Lippincott Williams \& Wilkins, Baltimore, USA 371

74. Saladin KS (2003) Anatomy \& Physiology: The Unity of Form and Function Surface anatomy. (3rdedn), The McGraw- Hill companies 396.

75. Saladin KS (2003) Anatomy \& Physiology: The Unity of Form and Function. Surface anatomy. (3rdedn), The McGraw- Hill companies 397.

76. Saladin KS (2003) Anatomy \& Physiology: The Unity of Form and Function Surface anatomy. (3rdedn), The McGraw- Hill companies 398.

77. El-Ghazzawy HA (2000) Islamic treatment using the European method.

78. Mahmoud HS (2013) Scientific and practical bases of the prophetic miracle, Alhijamah (In Arabic). (1stedn), Dar Al Afany for press, Cairo, Egypt 3: 107-112.

79. Sampanis Ch (2008) Management of hyperglycemia in patients with diabetes mellitus and chronic renal failure. Hippokratia 12: 22-27.

80. Alshowafi FK (2010) Effect of Blood Cupping on Some Biochemical Parameter Med J Cairo Univ 78: 311-315.

81. Shekarforoush S, Foadoddini M (2012) Cardiac effects of cupping: myocardia infarction, arrhythmias, heart rate and mean arterial blood pressure in the rat heart. Chin J Physiol 55: 253-258

82. Kamaratos AV, Tzirogiannis KN, Iraklianou SA, Panoutsopoulos GI, Kanellos IE, et al. (2012) Manuka honey-impregnated dressings in the treatment of neuropathic diabetic foot ulcers. Int Wound J.

83. Al-Waili NS, Salom K, Butler G, Al Ghamdi AA (2011) Honey and microbial infections: a review supporting the use of honey for microbial control. J Med Food 14: 1079-1096.

84. Moghazy AM, Shams ME, Adly OA, Abbas AH, El-Badawy MA, et al. (2010) The clinical and cost effectiveness of bee honey dressing in the treatment of diabetic foot ulcers. Diabetes Res Clin Pract 89: 276-281.

85. Makhdoom A, Khan MS, Lagahari MA, Rahopoto MQ, Tahir SM, et al. (2009) Management of diabetic foot by natural honey. J Ayub Med Coll Abbottabad 21: $103-105$.

86. Esposito S, Russo E, Noviello S, Leone S (2012) [Management of diabetic foot infections]. Infez Med 20: 28-34.

87. Akbari CM, Macsata R, Smith BM, Sidawy AN (2003) Overview of the diabetic foot. Semin Vasc Surg 16: 3-11.

88. Caputo GM, Cavanagh PR, Ulbrecht JS, Gibbons GW, Karchmer AW (1994) Assessment and management of foot disease in patients with diabetes. N Eng J Med 331: 854-860.

89. Sumpio BE, Lee T, Blume PA (2003) Vascular evaluation and arteria reconstruction of the diabetic foot. Clin Podiatr Med Surg 20: 689-708.

90. Pomposelli FB Jr, Marcaccio EJ, Gibbons GW, Campbell DR, Freeman DV, et 
Citation: Mahmoud HS, Abou-El-Naga M, Omar NAA, El-Ghazzawy HA, Fathy YM, et al. (2013) Anatomical Sites for Practicing Wet Cupping Therapy (Al-Hijamah): In Light of Modern Medicine and Prophetic Medicine. Altern Integ Med 2: 138. doi:10.4172/2327-5162.1000138

al. (1995) Dorsalis pedis arterial bypass: durable limb salvage for foot ischemia in patients with diabetes mellitus. J Vasc Surg 21: 375-384.

91. Gibbons GW, Marcaccio EJ Jr, Burgess AM, Pomposelli FB Jr, Freeman DV, et al. (1993) Improved quality of diabetic foot care, 1984 vs 1990. Reduced length of stay and costs, insufficient reimbursement. Arch Surg 128: 576-581.

92. Al-saedy SA, El-Hazemy MA, Hassan MI, Badawy AS, Bahr MH (2007) Studying molecular biology of Al-hijamah in patients with hepatitis $\mathrm{C}$ infection (In Arabic). Al-ljaz Al-IImy (Scientific miracle) 27: 28-37.

93. Ahmed SM, Madbouly NH, Maklad SS, Abu-Shady EA(2005) Immunomodulatory effects of blood letting cupping therapy in patients with rheumatoid arthritis. Egypt J Immunol 12: 39-51.

94. Barakat EM, El Wakeel LM, Hagag RS (2013) Effects of Nigella sativa on outcome of hepatitis C in Egypt. World J Gastroenterol 19: 2529-2536.

95. Bin Sayeed MS, Asaduzzaman M, Morshed H, Hossain MM, Kadir MF, et al. (2013) The effect of Nigella sativa Linn. seed on memory, attention and cognition in healthy human volunteers. J Ethnopharmacol 148: 780-786.

96. Lang M, Borgmann M, Oberhuber G, Evstatiev R, Jimenez K, et al. (2013) Thymoquinone attenuates tumor growth in ApcMin mice by interference with Wnt-signaling. Mol Cancer 12: 41.

97. Leong XF, Rais Mustafa M, Jaarin K (2013) Nigella sativa and Its Protective Role in Oxidative Stress and Hypertension. Evid Based Complement Alternat Med 2013: 120732

98. Kaatabi H, Bamosa AO, Lebda FM, Al Elq AH, Al-Sultan Al (2012) Favorable impact of Nigella sativa seeds on lipid profile in type 2 diabetic patients. J Family Community Med 19: 155-161.

99. Sabzghabaee AM, Dianatkhah M, Sarrafzadegan N, Asgary S, Ghannadi A (2012) Clinical evaluation of Nigella sativa seeds for the treatment of hyperlipidemia: a randomized, placebo controlled clinical trial. Med Arh 66: 198-200.

100. Jayachandran S, Balaji N (2012) Evaluating the effectiveness of topical application of natural honey and benzydamine hydrochloride in the management of radiation mucositis. Indian J Palliat Care 18: 190-195.

101. Abdulrhman M, El Hefnawy M, Ali R, Abdel Hamid I, Abou El-Goud A, et al (2013) Effects of honey, sucrose and glucose on blood glucose and C-peptide in patients with type 1 diabetes mellitus. Complement Ther Clin Pract 19: 1519.

102. Mat Lazim N, Abdullah B, Salim R (2013) The effect of Tualang honey in enhancing post tonsillectomy healing process. An open labelled prospective clinical trial. Int J Pediatr Otorhinolaryngol 77: 457-461.

103. Abdulrhman M, El Barbary NS, Ahmed Amin D, Saeid Ebrahim R (2012) Honey and a mixture of honey, beeswax, and olive oil-propolis extract in treatment of chemotherapy-induced oral mucositis: a randomized controlled pilot study. Pediatr Hematol Oncol 29: 285-292.

104. Robson V, Yorke J, Sen RA, Lowe D, Rogers SN (2012) Randomised controlled feasibility trial on the use of medical grade honey following microvascular free tissue transfer to reduce the incidence of wound infection. Br J Oral Maxillofac Surg 50: 321-327.

105. Abdulrhman MA, Mekawy MA, Awadalla MM, Mohamed AH (2010) Bee honey added to the oral rehydration solution in treatment of gastroenteritis in infants and children. J Med Food 13: 605-609.

106. Al-Romaiyan A, Jayasri MA, Mathew TL, Huang GC, Amiel S, et al. (2010) Costus pictus extracts stimulate insulin secretion from mouse and human islets of Langerhans in vitro. Cell Physiol Biochem 26: 1051-1058.

107. Annadurai RS, Jayakumar V, Mugasimangalam RC, Katta MA, Anand S, et al. (2012) Next generation sequencing and de novo transcriptome analysis of Costus pictus D. Don, a non-model plant with potent anti-diabetic properties. BMC Genomics 13: 663

108. Ragab AR, Elkablawy MA, Sheik BY, Baraka HN. Antioxidant and TissueProtective Studies on Ajwa Extract: Dates from Al-Madinah Al-Monwarah, Saudia Arabia. J Environ Anal Toxicol 3.

109. The holy Qur'an. Al-Anbiaa (prophets) chapter. Verse number 107. King Fahd complex for printing the holy Qur'an. 